\title{
Aerosol composition and the contribution of SOA formation over Mediterranean forests
}

Evelyn Freney $^{1}$, Karine Sellegri $^{1}$, Mounir Chrit ${ }^{2}$, Kouji Adachi $^{3}$, Joel Brito ${ }^{1}$, Antoine Waked ${ }^{1, a}$, Agnès Borbon ${ }^{1}$, Aurélie Colomb ${ }^{1}$, Régis Dupuy ${ }^{1}$, Jean-Marc Pichon ${ }^{1}$, Laetitia Bouvier ${ }^{1}$, Claire Delon ${ }^{4}$, Corinne Jambert ${ }^{4}$, Pierre Durand $^{4}$, Thierry Bourianne ${ }^{5}$, Cécile Gaimoz ${ }^{6}$, Sylvain Triquet ${ }^{6}$, Anaïs Féron ${ }^{6}$, Matthias Beekmann ${ }^{6}$, François Dulac $^{7}$, and Karine Sartelet ${ }^{2}$

${ }^{1}$ Laboratoire de Météorologie Physique, CNRS-Université Clermont Auvergne, UMR6016, 63117, Clermont Ferrand, France ${ }^{2}$ CEREA, Joint Laboratoire École des Ponts ParisTech - EDF R \& D, Université Paris-Est, 77455 Marne-la-Vallée, France

${ }^{3}$ Meteorological research institute, Atmospheric Environment and Applied Meteorology Research Department,

1-1 Nagamine, Tsukuba, Ibaraki 305-0052, Japan

${ }^{4}$ Laboratoire d'Aérologie, CNRS-Université de Toulouse, CNRS, UPS, Toulouse, France

${ }^{5}$ Centre National de Recherches Météorologiques, Météo-France-CNRS, Toulouse, URA1357, France

${ }^{6}$ Laboratoire Interuniversitaire des Systèmes Atmosphériques, LISA/IPSL, UMR CNRS 7583, Université Paris Est Créteil (UPEC), France

${ }^{7}$ Laboratoire des Sciences du Climat et de l'Environnement, LSCE/IPSL, UMR 8212 CEA-CNRS-UVSQ,

Université Paris-Saclay, Gif-sur-Yvette, France

a now at: IMT Lille Douai, Sciences de l'Atmosphère et Génie de l'Environnement (SAGE), 59508 Douai CEDEX, France

Correspondence: Evelyn Freney (evelyn.freney@uca.fr)

Received: 19 May 2017 - Discussion started: 18 July 2017

Revised: 27 March 2018 - Accepted: 4 April 2018 - Published: 23 May 2018

\begin{abstract}
As part of the Chemistry-Aerosol Mediterranean Experiment (ChArMEx), a series of aerosol and gas-phase measurements were deployed aboard the SAFIRE ATR42 research aircraft in summer 2014. The present study focuses on the four flights performed in late June early July over two forested regions in the south of France. We combine in situ observations and model simulations to aid in the understanding of secondary organic aerosol (SOA) formation over these forested areas in the Mediterranean and to highlight the role of different gas-phase precursors. The non-refractory particulate species measured by a compact aerosol time-of-flight mass spectrometer (cToF-AMS) were dominated by organics $(60$ to $72 \%)$ followed by a combined contribution of $25 \%$ by ammonia and sulfate aerosols. The contribution from nitrate and black carbon (BC) particles was less than $5 \%$ of the total $\mathrm{PM}_{1}$ mass concentration. Measurements of nonrefractory species from off-line transmission electron microscopy (TEM) showed that particles have different mixing states and that large fractions (35\%) of the measured particles were organic aerosol containing $\mathrm{C}, \mathrm{O}$, and $\mathrm{S}$ but without
\end{abstract}

inclusions of crystalline sulfate particles. The organic aerosol measured using the cToF-AMS contained only evidence of oxidized organic aerosol (OOA), without a contribution of fresh primary organic aerosol. Positive matrix factorization (PMF) on the combined organic-inorganic matrices separated the oxidized organic aerosol into a more-oxidized organic aerosol (MOOA), and a less-oxidized organic aerosol (LOOA). The MOOA component is associated with inorganic species and had higher contributions of $m / z 44$ than the LOOA factor. The LOOA factor is not associated with inorganic species and correlates well with biogenic volatile organic species measured with a proton-transfer-reaction mass spectrometer, such as isoprene and its oxidation products (methyl vinyl ketone, MVK; methacroleine, MACR; and isoprene hydroxyhydroperoxides, ISOPOOH). Despite a significantly high mixing ratio of isoprene (0.4 to $1.2 \mathrm{ppbV})$ and its oxidation products $(0.2$ and $0.8 \mathrm{ppbV})$, the contribution of specific signatures for isoprene epoxydiols SOA (IEPOXSOA) within the aerosol organic mass spectrum $(\mathrm{m} / z 53$ and $m / z 82$ ) were very weak, suggesting that the presence of 
isoprene-derived SOA was either too low to be detected by the cToF-AMS, or that SOA was not formed through IEPOX. This was corroborated through simulations performed with the Polyphemus model showing that although 60 to $80 \%$ of SOA originated from biogenic precursors, only about 15 to $32 \%$ was related to isoprene (non-IEPOX) SOA; the remainder was $10 \%$ sesquiterpene SOA and 35 to $40 \%$ monoterpene SOA. The model results show that despite the zone of sampling being far from industrial or urban sources, a total contribution of 20 to $34 \%$ of the SOA was attributed to purely anthropogenic precursors (aromatics and intermediate or semi-volatile compounds).

The measurements obtained during this study allow us to evaluate how biogenic emissions contribute to increasing SOA concentrations over Mediterranean forested areas. Directly comparing these measurements with the Polyphemus model provides insight into the SOA formation pathways that are prevailing in these forested areas as well as processes that need to be implemented in future simulations.

\section{Introduction}

The contribution of anthropogenic aerosol particles is thought to be of the order of $10 \mathrm{TgC}^{-1}$; however, that of natural biogenic aerosols has been estimated to be as much as $90 \mathrm{Tg} \mathrm{C} \mathrm{yr}^{-1}$, having an important effect on climate in both populated and remote areas of the world (IPCC, 2007; Hallquist et al., 2009). Our knowledge of how primary emissions from anthropogenic and natural sources contribute to the formation of secondary aerosols and their evolution in the atmosphere continues to improve with considerable advances in numerical simulations. However, discrepancies between simulations and measurements still exist and are more apparent over remote and forested environments than over anthropogenic environments (Ganzeveld et al., 2008; Lelieveld et al., 2008). The most commonly emitted biogenic volatile organic compounds (BVOCs) include isoprene and monoterpenes, with isoprene emissions accounting for approximately $44 \%$ (Kesselmeier and Staudt, 1999; Arneth et al., 2008). These species can be difficult to characterize because of their high temporal and spatial variability. Studies have shown that the formation yields of secondary organic aerosol (SOA) from biogenic emissions alone are relatively low compared to those from anthropogenic sources, but when emissions from both biogenic and anthropogenic sources are combined, the resulting yield for SOA formation is much higher than either anthropogenic or biogenic emissions alone (Day et al., 2009; Bryan et al., 2012; Shilling et al., 2013; Hu et al., 2015).

The increasing improvement of instrumentation (namely aerosol mass spectrometry) available for the detection of different biogenic species has led to an increase in the characterization of biogenic SOA in rural (Schwartz et al., 2010; Slowik et al., 2010; Setyan et al., 2014), boreal (Kulmala et al., 2000; Allan et al., 2006), Amazonian (Martin et al., 2010), and some other tropical and subtropical forests (Capes et al., 2009; Robinson et al., 2011). Using aerosol mass spectrometry, a number of studies have identified specific signatures for isoprene-derived SOA (Allan et al., 2014; Budisulistiorini et al., 2015). Hu et al. (2015) showed, through comparison with model simulations, that the global distribution of a particular SOA formation route from isoprene to epoxydiols is largely focused in the Southern Hemisphere and over Siberian forests far from anthropogenic emissions. The occurrence of these species in the Northern Hemisphere has been documented in several studies (Budisulistiorini et al., 2015), but in general the contribution is less than that reported in the South Hemisphere.

The Mediterranean region is thought to be extremely sensitive to climate change and is influenced by air masses from the Atlantic, continental Europe, and northern Africa, as well as increasing emissions from biomass burning, intense shipping, and from the increasing population density in Mediterranean coastal cities (e.g. Sciare et al., 2003; Barnaba and Gobbi, 2004; Lyamani et al., 2006; Alados-Arboledas et al., 2011; Mallet et al., 2013). Several studies have shown that during the summer months the aerosol radiative effect within the Mediterranean is one of the most significant in the world (Markowitz et al., 2002; Papadimas et al., 2012). Sartelet et al. (2012) modelled aerosol loading in Europe and North America and retrieved high concentrations of ozone and SOA over the Mediterranean Sea. It was estimated that biogenic emissions contributed to the formation of up to 72 $88 \%$ of the SOA over Europe. In order to better characterize the sources of SOA and its precursors over the Mediterranean, the SAFMED (Secondary Aerosol Formation in the Mediterranean) experiment took place in the Mediterranean as part of the Chemistry-Aerosol Mediterranean Experiment (ChArMEx; http://charmex.lsce.ipsl.fr/, last access: 22 January 2017) during Summer 2014. In this work, we present observations from four research flights over the forested Mediterranean region. The objectives of these flights were to combine both aerosol and gas-phase measurements to investigate the origin of SOA over these forested areas.

\section{Methodology}

\section{$2.1 \quad$ ATR42}

All airborne measurements were performed aboard the ATR42 research aircraft, run by SAFIRE (French aircraft service for environmental research; http://www.safire.fr, last access: 12 July 2016). The ATR (Avion de Transport Régional) is a turbo propeller aircraft approximately $23 \mathrm{~m}$ long and $25 \mathrm{~m}$ wide, with a payload of about $4.6 \mathrm{t}$ (www.atraircraft. com, last access: 22 October 2017). The aircraft was based in Avignon, France. Aircraft flight plans were decided depending on forecasts from meteorological and air quality models 
made available on a dedicated operational web server called the ChArMEx Operation Centre (ChOC; http://choc.sedoo. fr, last access: 22 April 2018). A series of different standard meteorological parameters were measured aboard the ATR42 including temperature, pressure, relative humidity, turbulence, wind speed, direction, and downward and upward radiances.

\subsection{Online aerosol chemical and physical properties}

In order to sample aerosol particle species, a forward facing aerosol inlet was fitted in place of a side window. This inlet is designed with an outer sleeve for channelling air and an inner tube with a large diameter and low curvature to limit particle losses due to deposition. This inlet is both isokinetic and isoaxial and has a 50\% sampling efficiency for aerosol particles with diameters of $4.5 \mu \mathrm{m}$ (Crumeyrolle et al., 2013). From the aerosol inlet, the sampled aerosols are directed through a manifold to a number of different instruments. Aerosol particle number concentrations were measured using a condensation particle counter (CPC, cut-off diameter $5 \mathrm{~nm}$ ) and scanning mobility particle sizer (SMPS) with 162 size channels for particle diameters ranging from $17 \mathrm{~nm}$ up to $400 \mathrm{~nm}$, with a time resolution of $84 \mathrm{~s}$. Measurements of aerosol chemical properties were performed using a compact aerosol time-of-flight mass spectrometer (cToFAMS) (Drewnick et al., 2005). This instrument was operating with a time resolution of $40 \mathrm{~s}$ in order to ensure that the maximum amount of spatial information (aircraft covers approximately $5 \mathrm{~km}$ in $40 \mathrm{~s}$ ) could be obtained while maintaining a high enough signal-to-noise ratio. Prior to being sampled into the cToF-AMS, aerosol particles passed through a pressurecontrolled inlet. This inlet maintained a constant pressure of about $400 \mathrm{hPa}$ throughout the duration of the flight (Bahreini et al., 2008). However, all reported concentrations are in standard temperature and pressure (used here $22^{\circ} \mathrm{C}, 950 \mathrm{hPa}$ ). In order to provide quantitative information on aerosol mass concentrations, a collection efficiency (CE) must be applied to the aerosol mass concentrations. This is based on the principle that the cToF-AMS aerodynamic inlet is designed to sample dry spherical particles and that particles with nonspherical shapes will not be as efficiently sampled. In addition to this, sampled aerosol particles can sometimes be lost in the instrument as a result of particle bounce on the heating filament. This CE correction is chemical dependant (Middlebrook et al., 2012); however since the contribution of nitrate and sulfate remained lower than $25 \%$ at all times, the CE remained at $50 \%$ throughout the sampling period. The total mass measured by the cToF-AMS (added to that from the black carbon (BC) measurements) was compared to the total aerosol concentration measured by the SMPS set-up (Fig. S1 in the Supplement). BC concentrations were obtained using a single-particle soot photometer (SP2, Droplet Measurement Technologies). Full details of this instrument are available in Baumgardner et al. (2007).

\subsection{Gas-phase measurements}

Gas-phase species were sampled on-board through a rearfacing 1/4 inch Teflon tube. Ozone and CO were measured using ultraviolet and infrared analysers (Thermo Fisher environmental instruments) (Nedelec et al., 2003). The NO and $\mathrm{NO}_{x}$ measurements were performed using an ozone chemiluminescence instrument (Environment SA AC42S instrument). The quantification of $\mathrm{NO}_{2}$ is obtained by converting $\mathrm{NO}_{2}$ to $\mathrm{NO}$ using a molybdenum converter at $320^{\circ} \mathrm{C}$. As some $\mathrm{NO}_{y}$ is also converted into $\mathrm{NO}$ in the molybdenum oven, the $\mathrm{NO}_{2}$ and $\mathrm{NO}_{x}$ concentrations can be overestimated. In this work, these measurements will be referred to as $\mathrm{NO}_{w}$, and represent $\mathrm{NO}+\mathrm{NO}_{2}+$ an unquantified $\mathrm{NO}_{y}$. For measurements of volatile organic compounds (VOCs), a unit mass resolution proton-transfer-reaction mass spectrometer (PTR-MS) from Ionicon Analytik (Innsbruck, Austria) was used, with a time resolution of $19 \mathrm{~s}$. Full details of the PTRMS configuration on-board and operating conditions are provided in Borbon et al. (2013). During the so-called biogenic flights, 16 protonated masses were monitored. Compounds of interest are

- VOCs of biogenic origin (BVOCs) and their first generation oxidation products including $\mathrm{m} / \mathrm{z} 69$ (isoprene), $m / z 71$ (sum of methyl vinyl ketone, MVK; methacroleine, MACR; and isoprene hydroxyhydroperoxides, ISOPOOH), $m / z 137$ (sum of monoterpenes);

- anthropogenic volatile organic compounds including $m / z 79$ (benzene), $m / z 93$ (toluene), $m / z 107$ (C8 aromatics), and $m / z 121$ (C9 aromatics);

- oxygenated VOCs including $m / z 33$ (methanol), $m / z 45$ (acetaldehyde), and $m / z 59$ (acetone).

Detection limits, defined as $3 \sigma$ of background mixing ratios ranged from 0.05 to $2.70 \mathrm{ppbV}$ over a $1 \mathrm{~s}$ dwell time. Instrumental background signal was determined through periodic air sampling (triplicates) of ambient air scrubbed through a custom-built catalyst converter (platinum-coated steel wool) heated to $250^{\circ} \mathrm{C}$. Three complete calibrations over a $0.1-$ $20 \mathrm{ppb}$ range were performed before, during, and after the campaign. The standard gas used was provided by Ionimed (Innsbruck, Austria) and contained several VOCs including isoprene, $\alpha$-pinene, benzene, toluene, and o-xylene at 1 ppmV certified at $\pm 5 \%$. A second parts-per-billion-level gaseous standard from NPL (UK) was used to cross-check the quality of the calibration and to perform regular onepoint calibration control for isoprene and C6-C9 aromatics $(4 \pm 0.8 \mathrm{ppbV})$. A relative difference of less than $10 \%$ was measured. The calibration factor for all major VOCs (the slope of the mixing ratio with respect to product ion signal normalized to $\left.\mathrm{H}_{3} \mathrm{O}^{+}\right)$ranged from $2.35(\mathrm{~m} / \mathrm{z} 137)$ to 18.9 $(m / z, 59)$ counts $\mathrm{s}^{-1}$. 

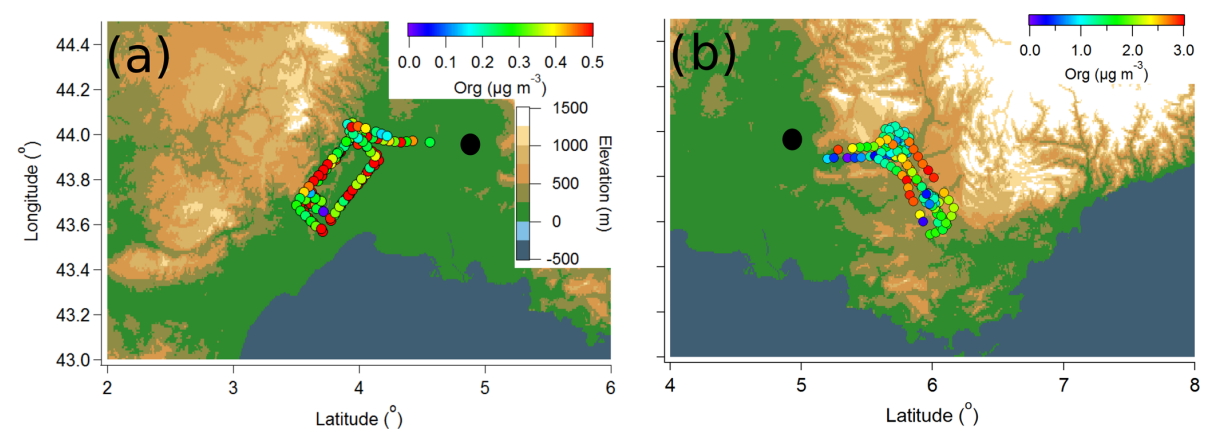

Figure 1. Typical flight track travelling (a) west (RF15 and RF21) and (b) east (RF20 and RF23) of Avignon (black circle). Points of the flight track are coloured by organic aerosol concentrations.

\subsection{Statistical analysis}

Detailed analysis of the organic aerosol mass spectra measured using the cToF-AMS was performed using positive matrix factorization (PMF) (Paatero and Tapper, 1994). The PMF2 software package was used in conjunction with the PMF evaluation tool (version 2.04; Ulbrich et al., 2009). Recommended procedures of down-weighting for certain $\mathrm{m} / \mathrm{z}$ values were followed (Ulbrich et al., 2009) as well as removal of several $\mathrm{m} / z$ values due to low $(\mathrm{m} / z 19$ and 20$)$ or high signal $(m / z 29)$. In this particular case, $m / z$ values from inorganic ions $\left(\mathrm{SO}_{4}, \mathrm{NO}_{3}\right)$ were equally combined with the organic matrices to better separate different factors. Error values for all $\mathrm{m} / \mathrm{z}$ values were calculated in the same way using the SQUIRREL software (version 1.53). The number of factors was determined using correlations with external factors (temporal series of VOC measurements). The reported correlations used later on in the discussion were calculated using simple linear regression.

\subsection{Electron microscopy analysis}

Aerosol particles were collected on transmission electron microscope (TEM) grids using a sampler consisting of two impactor stages. The $50 \%$ cut-off of each of these stages was calculated to be 1.6 and $0.2 \mu \mathrm{m}$, with a flow rate of approximately $1.0 \mathrm{~L} \mathrm{~min}^{-1}$. The samples were collected only when the aircraft was travelling at a constant altitude, usually lasting between 15 and $20 \mathrm{~min}$. The TEM grids on the submicron stage of the impactor were then analysed using a $120 \mathrm{kV}$ TEM (JEM-1400, JEOL) to provide detailed information on individual aerosol compositions and shapes. The advantage of having TEM analysis is the ability to detect both refractory and non-refractory aerosol particles. Composition of each sample collected was analysed using energy-dispersive Xray spectrometer (EDS) with scanning-TEM mode (Adachi et al., 2014). There were at least 230 particles analysed from each grid. Particles were classified into five aerosol categories based on their compositions: organic aerosol ( $\mathrm{C}$ dominant), sulfate ( $\mathrm{S}$ dominant), sulfate + organic ( $\mathrm{C}$ and $\mathrm{S}$ domi- nant), sea salt (Na dominant), and other (e.g. mineral dust ( $\mathrm{Si}$ is dominant, but also included traces of $\mathrm{Ca}$ and $\mathrm{K}$ )). Morphological differences between aerosol particles also allowed us to determine the extent of internal and external mixing. Organic aerosol generally had an amorphous morphology with no evidence of a crystal structure. EDS analysis of the homogeneously mixed amorphous particles showed that these particles contained $\mathrm{C}, \mathrm{O}$, and $\mathrm{S}$ without any evidence of crystalline structure. Sulfate particles (likely $\left(\mathrm{NH}_{4}\right)_{2} \mathrm{SO}_{4}$ ) had a crystalline structure and were sensitive to the electron beam (evaporation). Internal mixtures of organic and sulfate were mostly crystalline $\left(\mathrm{NH}_{4}\right)_{2} \mathrm{SO}_{4}$ surrounded by an amorphous carbon material.

\subsection{Back trajectory analysis}

In order to determine the history of air masses prior to being sampled by the aircraft, air mass trajectories were calculated for a $24 \mathrm{~h}$ period using the Lagrangian model HYSPLIT (http://ready.arl.noaa.gov/HYSPLIT.php, last access: 1 February 2018). These air mass trajectories were calculated for intervals of $5 \mathrm{~min}$ along the flight track and provide information on the dominant air mass sources during the flight. Back trajectories of $24 \mathrm{~h}$ provided enough information to determine whether air masses were slow moving and local or fast moving and arriving over larger distances (Fig. S2). For all flights, the air mass trajectory path was constant along the flight track at low altitudes, showing that air masses of the same origin were measured during each flight. $72 \mathrm{~h}$ back trajectories were also computed (although not shown) in order to determine possible aerosol sources over longer timescales.

\subsection{Overview of flights}

Four research flights (RF) dedicated to biogenic emissions were carried out: 30 June (RF15), 3 July (RF20), 5 July (RF21), and 7 July 2014 (RF23). Each flight was approximately $3.5 \mathrm{~h}$ in duration, and the aircraft flew over forested areas with elevations varying from 250 to $500 \mathrm{~m}$ above ground level (a.g.l.) during straight and level runs. The flight plan consisted of the aircraft leaving the city of Avi- 

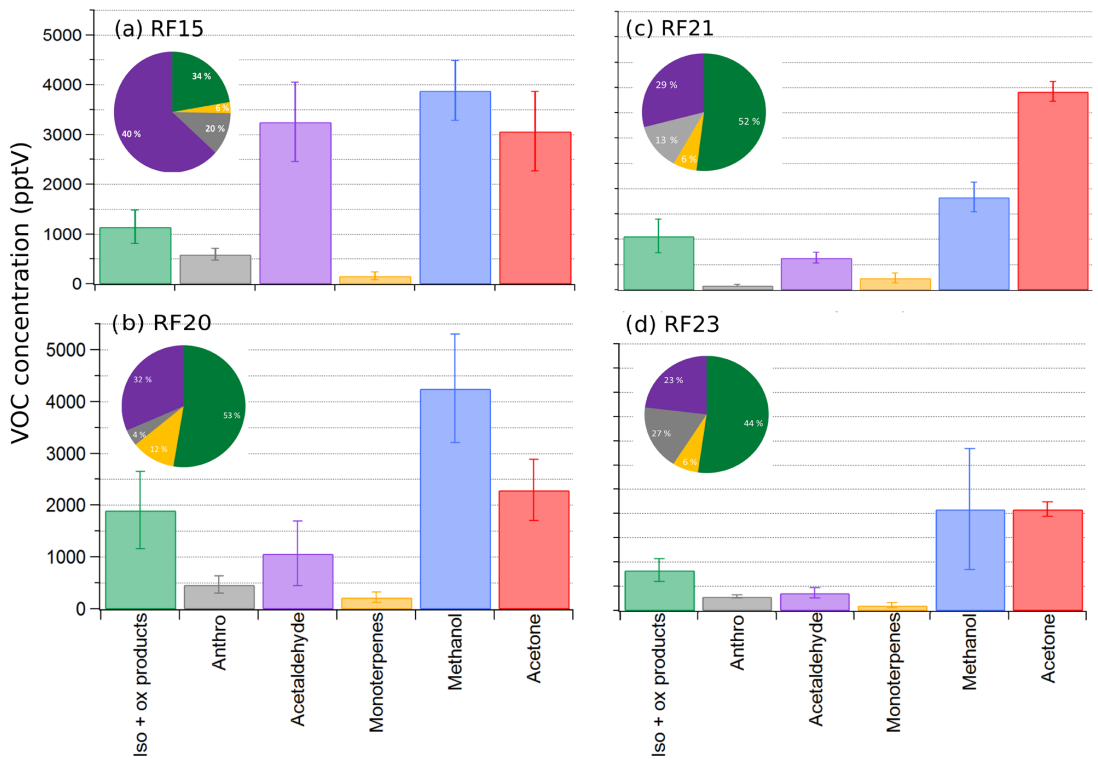

(d) RF23

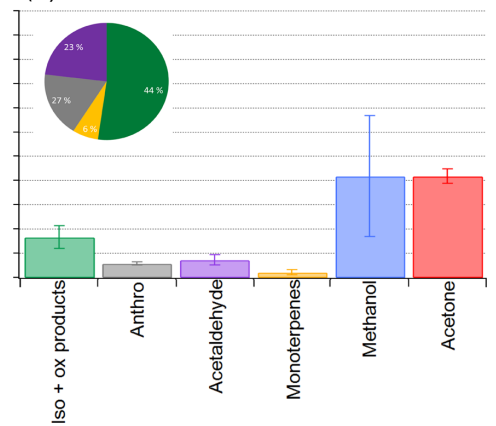

Figure 2. Contribution of the different measured gas-phase species aboard the ATR42: (a) RF15, (b) RF20, (c) RF21, (d) RF23. The pie charts illustrated in each figure represent the contribution of all VOC species except those of methanol and acetone.

gnon (southern France) and travelling east or west for about $50 \mathrm{~km}$ before starting a vertical sounding. Vertical soundings were performed from around 100 up to $3300 \mathrm{~m}$ above sea level (a.s.l.). Using the vertical profiles of VOC concentrations and relative humidity, the atmospheric boundary layer height was determined for each flight, and varied from $1300 \mathrm{~m}$ a.s.l. (RF20) up to $1900 \mathrm{~m}$ a.s.l. (RF15) (Fig. S3). Two of the flights (RF15, RF21) flew west over the Puéchabon Mediterranean national forest region (northwest of Montpellier, Fig. 1a), where the principle type of vegetation is evergreen oaks (Quercus ilex) and Alpine pines (halepensis). The evergreen oak is known to emit several different types of monoterpene species but mainly $\alpha$-pinene (Loreto et al., 1996). The other two flights (RF20, RF23) flew east over the Oak Observatory field site at Observatoire de Haute-Provence (O3HP, https://o3hp.obs-hp.fr, last access: 14 July 2016, Fig. 1b). This area is dominated by downy oak trees (Quercus pubescens) but also contains Montpellier maple (Acer monspessulanum) and smokey bushes (Cotinus coggygria) in a lower canopy stage. Since Quercus pubescens is the dominant type of vegetation, it makes this region a strong isoprene-emitting region and an ideal area to study isoprene chemistry and its relation to aerosol particles (Zannoni et al., 2015).

For the flight RF20, temperatures were stable, varying from 18 to $19^{\circ} \mathrm{C}$ in the boundary layer, and wind speeds were always less than $5 \pm 1 \mathrm{~m} \mathrm{~s}^{-1}$, originating from a southeasterly direction. HYSPLIT air mass back trajectories show that for a $24 \mathrm{~h}$ period prior to the measurements, air masses were slow moving and remained within a $200 \mathrm{~km}$ radius of the sampling site (Fig. S2b). This, together with the clear skies and relatively high temperatures, made ideal conditions to study local biogenic emissions. RF23 had similar temperatures to those recorded on RF20 $\left(17\right.$ to $\left.20^{\circ} \mathrm{C}\right)$, but with some cloud cover. Wind speeds ranged between 2 and $4 \mathrm{~m} \mathrm{~s}^{-1}$; air masses arrived from a southerly direction passing over the coast line prior to being sampled along the flight track (Fig. S2d). For the two westerly flights, average temperatures were slightly higher, with average values of $23 \pm 1{ }^{\circ} \mathrm{C}$. Wind speeds were low $\left(3 \pm 1 \mathrm{~m} \mathrm{~s}^{-1}\right)$. Air masses travelled much greater distances over the western (RF15) and northwestern (RF21) parts of France prior to being sampled (Fig. S2a, c).

\section{Results}

\subsection{Gas-phase properties}

The principal VOC species measured with the PTR-MS during all flights were acetone $(\mathrm{m} / \mathrm{z} 59)$ and methanol $(\mathrm{m} / \mathrm{z} 33)$, followed by isoprene $(\mathrm{m} / z 69)$ and its oxidation products (MVK + MACR + ISOPOOH) $(m / z 71)$ and then VOC species representative of monoterpene emissions $(m / z 137)$ (Fig. 2). Isoprene and its oxidation products showed a high temporal variation during flights, suggesting a more local influence of these VOC species. Monoterpene VOC, with a short atmospheric lifetime were measured in low concentration with little temporal evolution. Anthropogenic VOC species ( $m / z 93$ (toluene), $m / z 79$ (benzene), and C8 and C9 aromatics) never contributed more than $5 \%$ to the total VOCs measured (Table 1, Fig. 2). Despite this, we cannot ignore the presence of the anthropogenic VOC species measured during all flights. During westerly flights (RF15 and RF21), air masses arrived from the north (Fig. S2), possibly transporting accumulated anthropogenic emissions from over main- 
Table 1. Mean concentrations of the different gas-phase species measured during low and constant altitude of each flight. The error represents $\pm 1 \sigma$ on all the measurements.

\begin{tabular}{|c|c|c|c|c|c|c|c|c|c|c|c|}
\hline Flight & $\begin{array}{l}\text { Date } \\
(2014)\end{array}$ & $\begin{array}{r}\text { Isoprene } \\
(\mathrm{pptV})\end{array}$ & $\begin{array}{r}\text { MVK+ MACR } \\
+ \text { ISOPOOH } \\
(\mathrm{pptV})\end{array}$ & $\begin{array}{r}\text { Monoterpenes } \\
(\mathrm{pptV})\end{array}$ & $\begin{array}{r}\text { Toluene } \\
(\mathrm{pptV})\end{array}$ & $\begin{array}{r}\text { Benzene } \\
(\mathrm{pptV})\end{array}$ & $\begin{array}{r}\mathrm{C} 8+\mathrm{C} 9 \\
\text { aromatics } \\
(\mathrm{pptV})\end{array}$ & $\begin{array}{r}\mathrm{O}_{3} \\
(\mathrm{ppbV})\end{array}$ & $\begin{array}{r}\mathrm{CO} \\
(\mathrm{ppbV})\end{array}$ & $\begin{array}{r}\mathrm{NO}_{w} \\
(\mathrm{ppbV})\end{array}$ & $\begin{array}{r}\mathrm{NO} \\
(\mathrm{ppbV})\end{array}$ \\
\hline RF15 & 30 Jun & $583 \pm 290$ & $214 \pm 91$ & $117 \pm 82$ & $146 \pm 59$ & $93 \pm 61$ & $200 \pm 85$ & $40 \pm 8.8$ & $118 \pm 27$ & $4.2 \pm 0.8$ & $0.17 \pm 0.3$ \\
\hline RF20 & $3 \mathrm{Jul}$ & $1240 \pm 527$ & $756 \pm 287$ & $205 \pm 107$ & $149 \pm 82$ & $102 \pm 42$ & $196 \pm 79$ & $53 \pm 4.0$ & $136 \pm 46$ & $7.9 \pm 2.3$ & $0.31 \pm 0.2$ \\
\hline RF21 & $5 \mathrm{Jul}$ & $600 \pm 262$ & $365 \pm 182$ & $179 \pm 128$ & $147 \pm 176$ & $108 \pm 53$ & $135 \pm 39$ & $31 \pm 8.0$ & $79 \pm 11$ & $5.86 \pm 0.7$ & $0.29 \pm 0.3$ \\
\hline RF23 & $7 \mathrm{Jul}$ & $392 \pm 197$ & $230 \pm 159$ & $119 \pm 87$ & $74 \pm 34$ & $88 \pm 18$ & $125 \pm 36$ & $52 \pm 3.0$ & $88 \pm 9$ & $5.6 \pm 2.1$ & $0.29 \pm 0.9$ \\
\hline
\end{tabular}
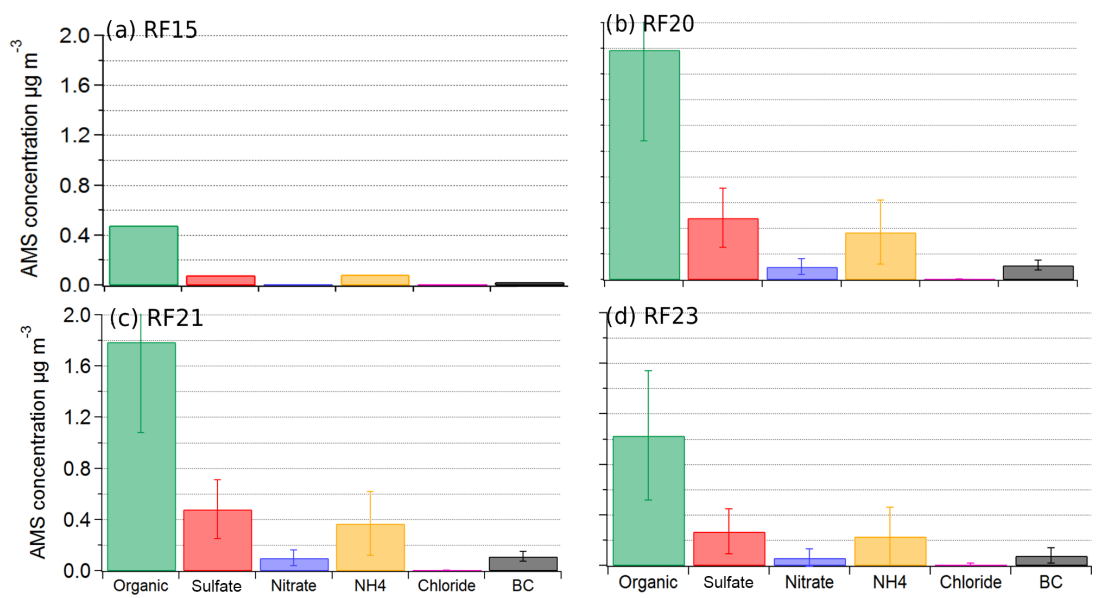

Figure 3. Contribution of the non-refractory aerosol chemical species aboard the ATR42: (a) RF15 3006 (b) RF20 0307, (c) RF21 0507, (d) RF23 0707.

land France. Easterly flights (RF20 and RF23), being principally influenced by local or southerly air masses, are likely impacted by anthropogenic activities over the Marseille and Fos sur Mer (Fos-Berre) industrial area.

\subsection{Aerosol chemical properties}

In the following section we will report average values for different chemical species measured during low and constant altitude parts of the flights (below the boundary layer height determined from the vertical profiles shown in Fig. S3). For all flights, the aerosol composition measured by the cToFAMS instrument shows that the organic compounds contributed a significant fraction to the total aerosol concentration (with average values of $72( \pm 36) \%$ for RF20 and 71 $( \pm 30) \%$ for RF23) (Table 2, Fig. 3). The second most dominant species measured were sulfate and ammonium aerosol particles, with a combined contribution of up to $25 \pm 10 \%$. The contribution from nitrate species was on average 3 $( \pm 1.5) \%$. BC measured using the SP2 never exceeded $5 \%$ of the total $\mathrm{PM}_{1}$ mass (Fig. 3). $\mathrm{O}: \mathrm{C}$ values were $1.05( \pm 0.05)$ for the total organic aerosol, with high $f_{44}>0.2$ and corresponding low $f_{43}<0.6$. These mass spectral signatures suggested that the majority of the organic aerosol was secondary, with little influence from fresh primary organic aerosol.
As described in Sect. 2.5, the chemical composition of aerosol particles collected on TEM grids was determined using EDS. At least 230 particles were analysed during each flight providing information of particle size and composition. The absolute number of particles analysed using offline electron microscopy is small in comparison to what is measured by online particle counters; however this technique provides us with a qualitative snapshot into particle mixing state, morphology, and composition. Only filters from the submicron stages are discussed here and showed that at least $35( \pm 5) \%$ of all aerosol particles measured were made up of homogeneously mixed amorphous (no evidence of a crystal structure) particles. EDS analysis showed that these amorphous particles were composed of homogeneously distributed C, $\mathrm{O}$, and S (Fig. 4a.i, ii, iii). The molecular structure of these compounds is unknown. Externally mixed crystalline sulfate particles contributed $15 \%( \pm 5 \%)$, and $10 \%$ were internally mixed amorphous $\mathrm{C}$ and crystalline sulfate (likely ammonium sulfate) species (Figs. 4b, S4). The remaining fractions contained signals for sea salt $(\mathrm{Na} \mathrm{Cl})$ and dust $(\mathrm{Si}, \mathrm{Ca})$ particles.

\subsection{Aerosol physical properties}

Aerosol number concentrations and size distributions were measured using a CPC and SMPS (respectively) during the 
Table 2. Concentrations $\left(\mu \mathrm{g} \mathrm{m}^{-3}\right)$ of the different chemical species measured aboard each flight during low-altitude legs. Error values are standard deviations calculated on the mean values of the measurements.

\begin{tabular}{llrrrrr}
\hline Flight & $\begin{array}{l}\text { Date } \\
(2014)\end{array}$ & $\begin{array}{r}\text { NR-PM1 } \\
\mu \mathrm{g} \mathrm{m}^{-3}\end{array}$ & $\begin{array}{r}\text { Org } \\
\mu \mathrm{g} \mathrm{m}^{-3}\end{array}$ & $\begin{array}{r}\mathrm{SO}_{4} \\
\mu \mathrm{g} \mathrm{m}^{-3}\end{array}$ & $\begin{array}{r}\mathrm{NO}_{3} \\
\mu \mathrm{g} \mathrm{m}^{-3}\end{array}$ & $\begin{array}{r}\mathrm{BC} \\
\mu \mathrm{g} \mathrm{m}^{-3}\end{array}$ \\
\hline RF15 & 30 Jun & $0.70 \pm 0.08$ & $0.48 \pm 0.23$ & $0.08 \pm 0.07$ & $0.013 \pm 0.01$ & $0.03 \pm 0.02$ \\
RF20 & 3 Jul & $2.70 \pm 1.10$ & $1.79 \pm 0.70$ & $0.48 \pm 0.2$ & $0.10 \pm 0.06$ & $0.11 \pm 0.03$ \\
RF21 & 5 Jul & $0.99 \pm 0.50$ & $0.72 \pm 0.40$ & $0.20 \pm 0.09$ & $0.03 \pm 0.02$ & $0.11 \pm 0.04$ \\
RF23 & 7 Jul & $1.64 \pm 0.70$ & $0.96 \pm 0.60$ & $0.30 \pm 0.18$ & $0.06 \pm 0.07$ & $0.08 \pm 0.06$ \\
\hline
\end{tabular}

(a) Homogeneously mixed amorphous organic aerosol particle
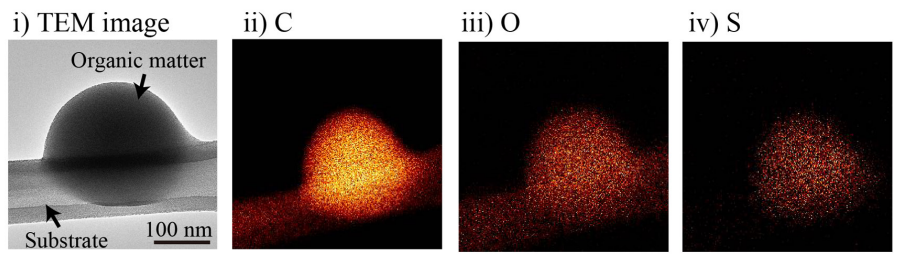

(b) Internally mixed organic aerosol particle with sulfate
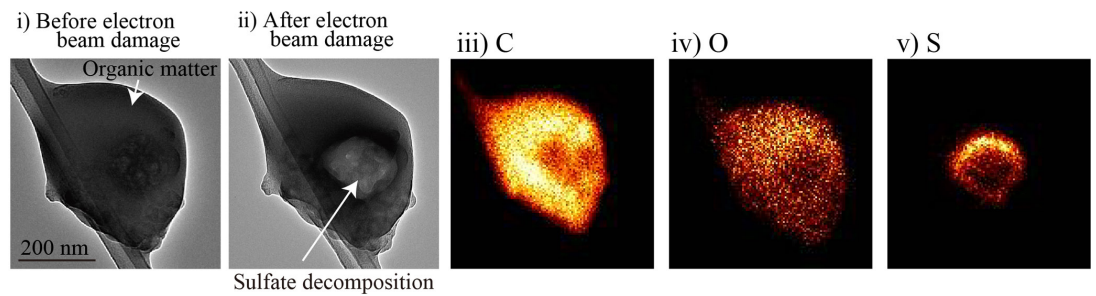

Figure 4. Panel (a) shows (i) an example of an amorphous particle deposited on a carbon substrate. EDS mapping analysis showing signals for (ii) carbon, (iii) oxygen, and (iv) sulfur. (b) Internally mixed amorphous particles with signals (i) before and (ii) after electron beam damage. EDS analysis showing signals for (iii) carbon, (iv) oxygen, and (v) sulfur.

four biogenic flights (Fig. 5). During the westerly flight RF15, when air masses were travelling from the northwest of France, particle concentrations were on average $1500 \pm 300 \mathrm{~cm}^{-3}$ and the principle size mode was less than $90 \mathrm{~nm}$ at altitudes of around $500 \mathrm{~m}$. At higher altitudes aerosol number concentration decreased to $600 \pm 200 \mathrm{~cm}^{-3}$ with modal diameters of around $30 \pm 20 \mathrm{~nm}$ (Fig. 5a). The measured particle concentrations during the other westerly flight, RF21, were on average $1895 \pm 1707 \mathrm{~cm}^{-3}$. The fraction of fine particles, $<40 \mathrm{~nm}$ in diameter (F40), measured during these flights was high, explaining the lower aerosol mass measured using the cToF-AMS instrument (Table 2). During the two easterly flights, average aerosol number concentrations were considerably higher at $3332 \pm 1920 \mathrm{~cm}^{-3}$ than the westerly flights (Fig. $5 b$ and d). The size distribution of the aerosol had a single mode at around $100 \mathrm{~nm}$. However, during periods with increased aerosol concentrations, the size distribution spectra showed an additional mode between 20 and $40 \mathrm{~nm}$ (nucleation-mode particles). Calculating the difference in aerosol particle concentrations measured by the CPC (cut-off $5 \mathrm{~nm}$ ) from that measured by the SMPS, we were able to determine the contribution of nucleation-mode particles.

The increases in fine-mode particles measured at lower altitudes ( $\sim 500 \mathrm{~m}$ a.g.l.) during all flights are likely linked to new particle formation. Observations of new particle formation from biogenic emissions have been reported over Boreal forests (Sihto et al., 2006), European coniferous forests (Held et al., 2004), and African savannah forests (Laakso et al., 2013), as well as during laboratory studies (KiendlerScharr et al., 2009). Monoterpene oxidation products were shown to produce new particles more efficiently by nucleation than the isoprene oxidation products (Spracklen et al., 2008; Bonn et al., 2014). Some of these studies have also shown that high concentrations of isoprene relative to monoterpenes can inhibit new particle formation (KiendlerScharr et al., 2009; Kanawade et al., 2011), although the underlying processes are not yet clear. Calculating the ratio of isopreneC / monoterpeneC (carbon associated with isoprene / monoterpene) and comparing it to the number con- 


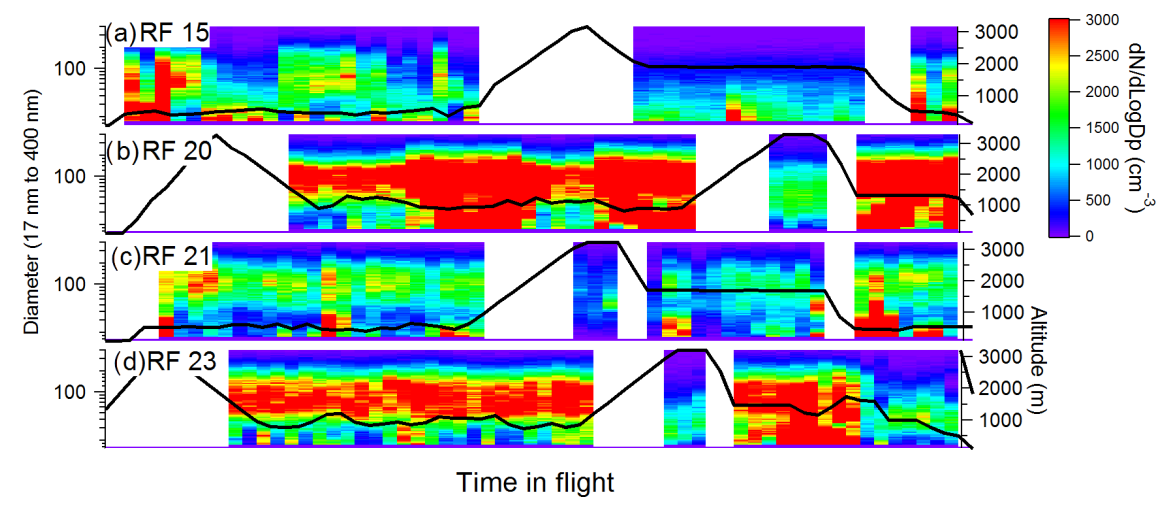

Figure 5. Aerosol size distribution measured with the SMPS for (a) RF15 (b) RF20, (c) RF21, and (d) RF23 from 17 up to $400 \mathrm{~nm}$. The colour scale indicates aerosol concentration $\mathrm{d} N / \mathrm{d} \log D_{p}$. Altitude is illustrated as the black line and is represented on the right-hand axis.

centration of nucleation-mode particles (Fig. 6), this relationship between biogenic VOC species and nucleation-mode particles was investigated. As a result of the low time resolution of the SMPS, we were limited to a small number of points per flight. Data were combined for all flights, giving average ratios of isopreneC / monoterpeneC varying between 0.05 and 8 (average $3 \pm 1$ ), with the lowest values corresponding to the highest fractions of fine-particle concentrations. Although the variation among points is high, the general trend of these observations is in agreement with previous field studies over mixed deciduous forests (Kanawade et al., 2011) and with laboratory studies in controlled environments showing that high concentrations of monoterpenes relative to isoprene can favour new particle formation (Kiendler-Scharr et al., 2009). The average ratios of isopreneC / monoterpeneC measured during these Mediterranean flights were higher than those reported in Finnish forests (ratios of 0.18) and lower than the ones measured in Michigan (ratios of 26.4) and Amazonian forests (ratios of 15.2) (Kanawade et al., 2011). In general, high ratios are associated with a very low or a suppressed number of new particle formation events.

\subsection{Secondary organic aerosol}

From cToF-AMS measurements, average mass concentrations measured during the two easterly flights were approximately $2.0 \pm 0.5 \mu \mathrm{g} \mathrm{m}^{-3}$, whereas those measured by the westerly flights were considerably less at approximately $1 \mu \mathrm{g} \mathrm{m}^{-3}$, making more detailed analysis of aerosol chemical properties difficult. For this reason the remaining analysis is focused on the two easterly flights.

For both easterly flights, increases in organic aerosol concentrations were observed in the valley area between the two high-elevation zones (between 43.6 and $43.8^{\circ} \mathrm{N}$ ) during horizontal transects of the flight. For RF20, these increases were accompanied by significant increases in the fine particulate matter between 20 and $40 \mathrm{~nm}$, and also those at $90 \mathrm{~nm}$. In addition, increases in the ratio of isoprene oxidation products to isoprene were observed in the same region, implying a more oxidized air mass. A time series plot of total organic aerosol (OA) with MACR + MVK + ISOPOOH shows a good relationship (Fig. S5a), and plotting the OA concentration against the ratio of MACR + MVK + ISOPOOH / isoprene provides us with a means to observe the evolution of the organic aerosol with the relative age of the air mass with respect to biogenic emissions (Fig. S5b). The ratios of MACR + MVK + ISOPOOH / isoprene measured during this flight are comparable to those measured over this forested area ( 0.4 to 0.8 ) during ground-based measurements (Zannoni et al., 2016). We observe a reasonable correlation $(r=0.46)$ and positive slope $(b=1.1)$ with increasing OA as the relative air mass age increases, suggesting that SOA formation is likely to have originated from biogenic precursors. Similar plots were prepared using anthropogenic precursor gases toluene and benzene (Fig. S6), showing a negative correlation with increasing organic mass concentration of $r=0.35$ and a slope of -0.56 . However, as the toluene and benzene concentrations are both close to the detection limit, care needs to be taken when interpreting these ratios. Generally, although anthropogenic precursor species are present, the VOC concentrations and trends measured suggest that the increases in OA concentrations are primarily related to biogenic emissions.

In order to extract additional information on the OA measured during the flights, we performed PMF analysis. Since the temporal evolution of both the organic and inorganic concentrations was similar, we chose to combine the mass spectral signatures for $\mathrm{SO}_{4}$ and $\mathrm{NO}_{3}$ into the PMF matrix alongside those of the organic species. Mass spectral signatures of $\mathrm{NH}_{4}$ were not included since higher "noise" was associated with these $m / z$ values. Adding the inorganic signals into the PMF matrix allows us to separate different aerosol sources and not only those related to organic compounds. For both flights a two-factor solution ( $f$-peak 0$)$ was chosen to best describe the sources of the aerosol particles and those two factors have maximum correlations with external 


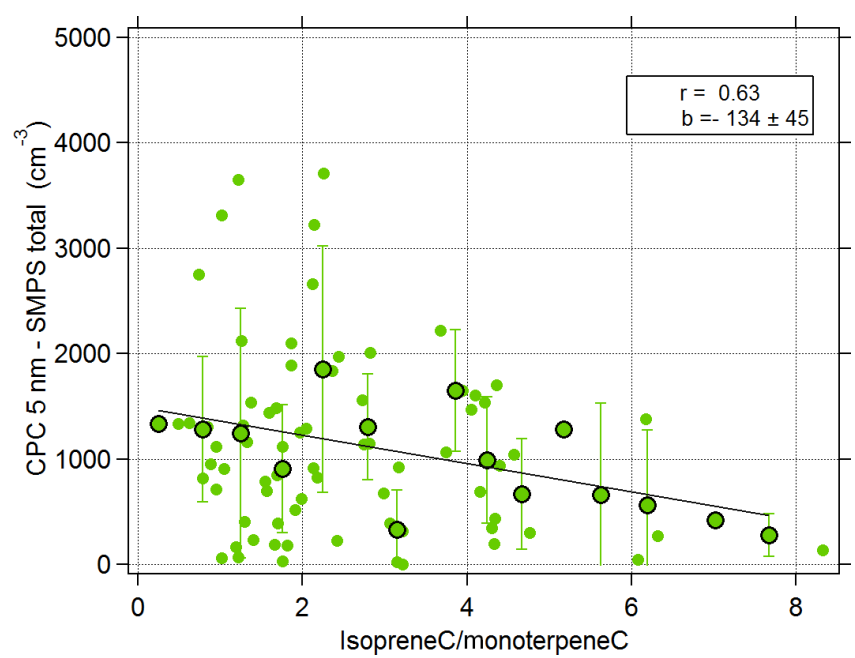

Figure 6. Ratios of isoprenec / monoterpeneC plotted as a function of the nucleation-mode particles (difference between the CPC (cutoff $5 \mathrm{~nm}$ ) and the SMPS (cut-off $17 \mathrm{~nm}$ )). Values for the four biogenic flights, as well as average values calculated over a number of isoprenec / monoterpeneC ratios are included (size bins of 0.5). Error bars represent $\pm 1 \sigma$ of the average CPC $5 \mathrm{~nm}$ - SMPS values. The black line represents the linear correlation fit.

species (Table 3). Additional details of the PMF analysis are included in Figs. S7 to S9 as well as Table S1 in the Supplement. The two resolved factors include (i) a more-oxidized organic aerosol (MOOA, contributing $55 \%$ to the resolved factors), containing high contributions from $m / z 44$ and associated with inorganic peaks $\left(m / z 30,46\left(\mathrm{NO}_{3}\right)\right.$, and 48 , 64 , and $\left.80\left(\mathrm{SO}_{4}\right)\right)$, and (ii) a less-oxidized organic aerosol species (LOOA, contributing $45 \%$ ) with little contribution from inorganic $m / z$ (Fig. 7a). These two factors MOOA and LOOA are very similar to the OOA- 1 and OOA- 2 species identified from ground-based measurements during a biogenic event over a forested area in Canada (Slowik et al., 2010). Slowik et al. (2010) showed similar trends with the two identified oxidized organic aerosols, where one was associated with inorganic aerosols and the other was not correlated with inorganic aerosols, while the other was well correlated with biogenic VOC species.

During the flights, as the valley area is approached, we observe the sampled air masses becoming gradually more oxidized with respect to biogenic emissions, providing us with a well-defined sample area to evaluate the contribution of biogenic SOA on background and/or regional air masses. In order to isolate the formation of $\mathrm{OA}$ resulting from the oxidation of VOC species, the change in the OA concentrations above the background was calculated ( $\Delta \mathrm{Org})$. The background values were determined based on measurements during transects of the flight between the valley area and the airport. During this time, aerosol concentrations were low with little temporal variation. Particle size measurements display a single mode at $100 \mathrm{~nm}$ with average particle con-
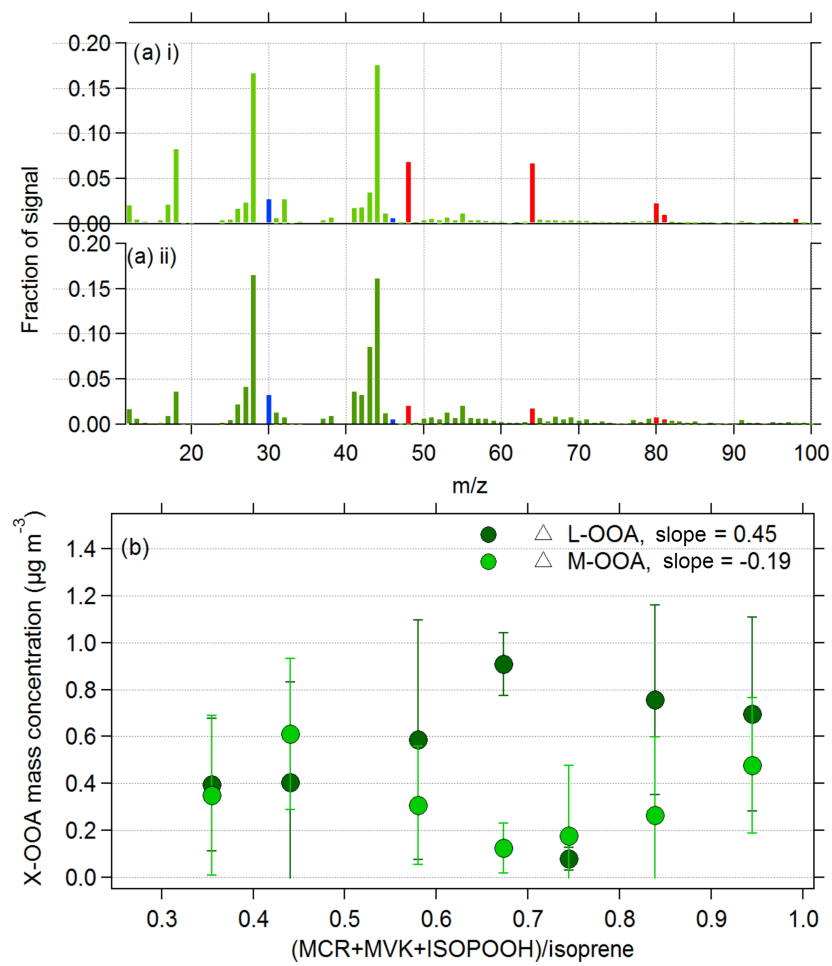

Figure 7. (a) A two-factor solution determined from PMF analysis of the biogenic research flights. (i) The more-oxidized organic aerosol (MOOA) associated with inorganic peaks for sulfate (red) and nitrate (blue); (ii) the less-oxidized organic aerosol (LOOA) with a lower contribution of inorganic peaks. (b) Variations of these two species with aging air mass (using MACR + MVK + ISOPOOH as a proxy for photochemical age of air mass). The delta values $(\Delta)$ are calculated based on background concentrations measured outside of the study region.

centrations of $3000 \mathrm{~cm}^{-3}$. Measurements of VOC species during this background period result in average concentrations of isoprene of $1544 \pm 696 \mathrm{pptV}$ and lower concentrations of longer-lived species MACR + MVK + ISOPOOH of $661 \pm 239 \mathrm{pptV}$ (Table S2).

For the resolved PMF factors, LOOA and MOOA, background values were determined to be 0.27 and $0.41 \mu \mathrm{g} \mathrm{m}^{-3}$, respectively, (Table S2). Organic factors corrected for background concentrations are referred to as $\Delta$-LOOA and $\Delta$ MOOA. Plotting these two factors against the ratio of $\mathrm{MACR}+\mathrm{MVK}+\mathrm{ISOPOOH} /$ isoprene (relative air mass age) (Figs. 7 and S10), we observe a significant increase in the $\Delta$-LOOA species with air mass age until a maximum is reached at ratios of 0.65 . Given that MOOA does not change with the relative air mass age in the measured area, and that it is associated with $\mathrm{SO}_{4}$ and $\mathrm{NO}_{3}$ species, it is reasonable to suggest that the MOOA is associated with long-rangetransported aerosol. A slower increase in concentrations of LOOA at higher ratios suggests that as the relative photochemical age of the air mass increases, LOOA becomes more oxidized and is converted to MOOA, as has recently been 
Table 3. Pearson $r$ (Pr) correlations for different time series during RF20 and RF23.

\begin{tabular}{|c|c|c|c|c|}
\hline & \multicolumn{2}{|c|}{ MOOA } & \multicolumn{2}{|c|}{ LOOA } \\
\hline & $\begin{array}{r}\text { RF20 } \\
\operatorname{Pr}(n=91)\end{array}$ & $\begin{array}{r}\text { RF23 } \\
\operatorname{Pr}(n=144)\end{array}$ & $\begin{array}{r}\text { RF20 } \\
\operatorname{Pr}(n=91)\end{array}$ & $\begin{array}{r}\text { RF23 } \\
\operatorname{Pr}(n=169)\end{array}$ \\
\hline PTR-MS $m / z 69$ (isoprene) & 0.11 & 0.41 & 0.51 & 0.67 \\
\hline PTR-MS $m / z 71(\mathrm{MVK}+\mathrm{MACR}+\mathrm{ISOPOOH})$ & 0 & 0.28 & 0.64 & 0.71 \\
\hline PTR-MS $m / z 137$ & 0.59 & 0.58 & 0.29 & 0.49 \\
\hline PTR-MS $m / z 93$ & 0.15 & 0.25 & 0.27 & 0.38 \\
\hline PTR-MS $m / z 79$ & 0.04 & 0.21 & 0 & 0.15 \\
\hline $\mathrm{BC}$ & 0.52 & 0.48 & 0.61 & 0.48 \\
\hline $\mathrm{CO}$ & 0.37 & 0.48 & 0.34 & 0.60 \\
\hline $\mathrm{NO}_{w}$ & 0.56 & 0.44 & 0.51 & 0.60 \\
\hline
\end{tabular}

illustrated in chamber experiments by Palm et al. (2018). Plotting these two factors as a function of air mass age using anthropogenic VOC species (ratio of toluene / benzene), we observe a relatively flat and decreasing trend (Fig. S10a). These observations would suggest the contribution of toluene and benzene, although not insignificant, plays a lesser role in the formation of the SOA measured during these flights.

Given the good correlation between the LOOA and isoprene and its oxidation products, we investigated the possibility of identifying isoprene-derived SOA. Several recent publications have identified signature peaks in aerosol mass spectrometry for isoprene-derived SOA using the $m / z 53$ and $\mathrm{m} / \mathrm{z} 82$ (ionization products of IEPOX) (Allan et al., 2014; Budisulistiorini et al., 2015; Zhang et al., 2017). In this study, the contribution of these peaks in both types of spectra was very low (fraction of signal $<0.004$ ), although somewhat more pronounced for LOOA. These contributions are similar to background contributions of $f_{82}$ (fraction of $m / z 82$ to the total organic signal) observed globally by $\mathrm{Hu}$ et al. (2015) and Lee et al. (2016), ranging from 0.0002 to 0.0035 , and would lead us to believe that we have no significant contributions of $f_{82}$ in our aerosol mass spectra. Factors influencing the formation of isoprene SOA include aerosol acidity and the presence of $\mathrm{NO}_{x}$ and sulfate (Nguyen et al., 2014), with the highest yields of isoprene SOA being measured under low- $\mathrm{NO}_{x}$ conditions $(<30 \mathrm{pptV})$ and in the presence of acidic aerosols (Gaston et al., 2014). Aerosol concentrations measured with the cToF-AMS appear to be fully neutralized with little evidence of acidity (Fig. S11), and the $\mathrm{NO}_{w}$ concentrations measured during these flights varied from 6 up to $10 \mathrm{ppbV}$; however the average concentrations of NO were $0.30 \pm 0.2 \mathrm{ppbV}$, suggesting that the real contribution of $\mathrm{NO}_{x}$ (see Sect. 2.3) is also likely to be low, but still higher than parts-per-trillion-level concentrations measured in truly remote forested areas. There have been some reports of isoprene-derived SOA formation (hereafter isoprene SOA) in high-NO regions but the contribution of this pathway is considered to be much smaller (Jacobs et al., 2014).
Other sources of biogenic SOA can originate from the oxidation of monoterpene and sequesterpene VOC species, or additionally from isoprene SOA, that do not follow the IEPOX route. In both cases, the contribution of $m / z 91$ in the cToF-AMS mass spectra, often identified as being the $\mathrm{C}_{7} \mathrm{H}_{7}^{+}$fragment (Lee et al., 2016; Riva et al., 2016), would be enhanced. This $m / z 91$ was present in all OA mass spectra and was higher for the LOOA $\left(f_{91}=0.007\right)$. However, in previous studies these $f_{91}$ values are considered background (Hu et al., 2015; Lee et al., 2016), hence making it difficult to associate the measured SOA with these formation routes. It should be noted that $m / z 91$ can also be associated with fragments of primary anthropogenic OA, and the contribution of anthropogenic aerosols from the industrial zone (Fossur-Mer) south of the flight area cannot be ruled out.

In general, the yield of formation of SOA from the isoprene VOC precursor is relatively low compared to other biogenic species such as monoterpenes, and also compared with aromatic precursors (Ait-Helal et al., 2014). Since the measured aerosol particles are neutralized (Fig. S11) and the measured NO concentrations are still reasonably high $(0.30 \mathrm{ppbV})$, we assume that isoprene-derived SOAs, following the IEPOX formation route, do not contribute significant amounts to the OA measured during these flights. Given the increase in OA with the relative biogenic air mass age, we could suspect that additional sources of SOA could originate from other isoprene SOA formation routes and/or terpene precursors. This is also coherent with the increase in the number concentrations of fine particles at the lower isopreneC / monoterpeneC ratios discussed in Sect. 3.3.

\subsection{Model evaluation of secondary organic aerosol formation}

In order to evaluate the relative contribution of the different gaseous precursors to SOA formation over these forested regions, two simulations were performed using the Polyphemus model. Full details of the model set-up are available in Chrit et al. (2017). The domain of the air quality simulation has a horizontal resolution of $0.125^{\circ} \times 0.125^{\circ}$, while 

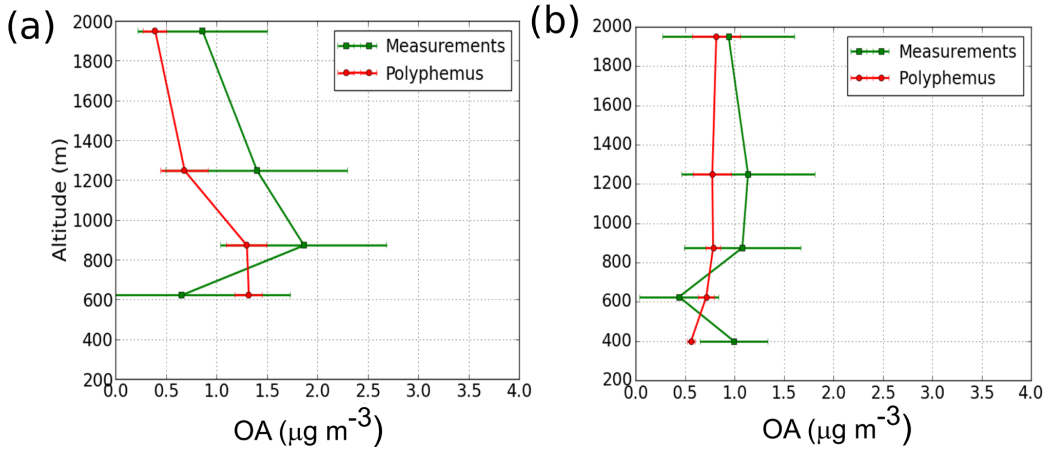

Figure 8. Measured (green) and modelled (red) organic concentration during the (a) RF20 and (b) RF23 flights. The concentrations are averaged on the vertical layers of the model and variations around the average are indicated by the horizontal error bars.

the vertical is modelled with 14 layers with interface heights at $0,30,60,100,150,200,300,500,750,1000,1500,2400$, 3500, 6000, and $12000 \mathrm{~m}$ a.s.l. (Fig. S12). Biogenic emissions are computed using MEGAN (Guenther et al., 2006), and anthropogenic emissions are computed using HTAP-v2 (http://edgar.jrc.ec.europa.eu/htap_v2/, last access: 11 December 2017). Initial and boundary conditions are obtained from a larger-scale simulation (over Europe), as detailed in Chrit et al. (2018). For gaseous chemistry, a carbonbound approach model is used (CB05; Yarwood et al., 2005). Aerosol dynamics is modelled with a sectional approach (SIREAM; Debry et al., 2007), and for SOA modelling, a surrogate approach is used (Couvidat et al., 2012). The modelling of SOA formation is based on smog chamber experiments, which provide information on SOA yield as a function of organic mass concentration for each precursor using an Odum approach (Odum et al., 1996). Stoichiometric coefficients of SOA surrogates and their saturation vapour pressures are selected to fit data from smog chambers. Candidates for SOA surrogates are estimated from the literature (Couvidat et al., 2012). Biogenic precursors are isoprene, monoterpenes (with $\alpha$-pinene and limonene as surrogates), and sesquiterpenes, with low- $\mathrm{NO}_{x}$ and high- $\mathrm{NO}_{x}$ oxidation regimes. Isoprene may form two surrogates, amongst which are methyl methyl dihydroxy dihydroperoxide under low $\mathrm{NO}_{x}$, and methyl glyceric acids under high $\mathrm{NO}_{x}$. Monoterpenes may form pinonaldehyde, norpinic acid, pinic acid, 3-methyl-1, 2, 3-butanetricarboxylic acid under low$\mathrm{NO}_{x}$ conditions, and organic nitrate, as well as extremely low-volatility organic carbons (ELVOCs) or highly oxidized multifunctional organic compounds (HOMs) by ozonolysis. Anthropogenic precursors are toluene, xylene, and intermediate or semi-volatile organic compounds (I/SVOCs). Gasphase emissions of I/SVOCs are estimated by multiplying emissions of primary organic aerosols by a factor 1.5 (Zhu et al., 2016). Partitioning between the gas and aerosol phases is carried out with a secondary organic aerosol processor model (Couvidat and Sartelet, 2015) for organics and inorganic aerosol model ISORROPIA for inorganics (Nenes et al., 1998). Maps of the simulated submicron organic matter $\left(\mathrm{OA}_{1}\right)$ are shown in Fig. S12a and b for the two easterly flights RF20 and RF23, respectively.

Figure 8 compares the vertical profiles of measured and modelled $\mathrm{OA}_{1}$ during the RF20 and the RF23 flights. The concentrations averaged over the vertical layers of the model and the standard deviations around the mean concentrations are shown. The measured concentrations have higher standard deviations than the modelled concentrations due to the coarse horizontal model resolution $\left(0.125^{\circ} \times 0.125^{\circ}\right)$. For both flights there are some differences between the model and the measurements. However, this discrepancy may be due to difficulties in representing the vertical distribution of pollutants above the canopy. Although the mean vertical concentrations of $\mathrm{OA}_{1}$ tend to be underestimated over $1000 \mathrm{~m}$, they are on average well modelled under $1000 \mathrm{~m}$ within the boundary layer for both flights.

Although isoprene emissions are 2.5 times higher than those of monoterpenes and 11.6 times higher than those of sesquiterpenes over that region during the period of simulation, isoprene-derived SOA represents about 15 to $35 \%$ of the simulated OA, which is lower than the monoterpene-derived SOA that represents 35 to $40 \%$. Sesquiterpene-derived SOA represents about $10 \%$. Amongst those monoterpene-derived SOAs, 4 to $7 \%$ are monoterpene products (first-generation semi-volatile organic compounds: pinic acid, norpinic acid, and pinonaldehyde), 9 to $14 \%$ are ELVOCs or HOMs, and 17 to $23 \%$ are organic nitrate. In total, biogenic-derived OA represents about 66 to $80 \%$ of OA. The rest is made up by aromatic-derived OA ( 2 to $3 \%$ ) and anthropogenic intermediate and semi-volatile organic compounds (17 to $31 \%$ ) (Fig. 9). The contribution of organic nitrate modelled is not reflected in the measurements where less than $5 \%$ of the total measured mass was nitrate aerosol. This difference may be due to hydrolysis not being accounted for in the model. Under ambient conditions hydrolysis could eliminate the organic nitrate functionality, allowing nitric acid to evaporate from the particles (Rindelaub et al., 2016). 

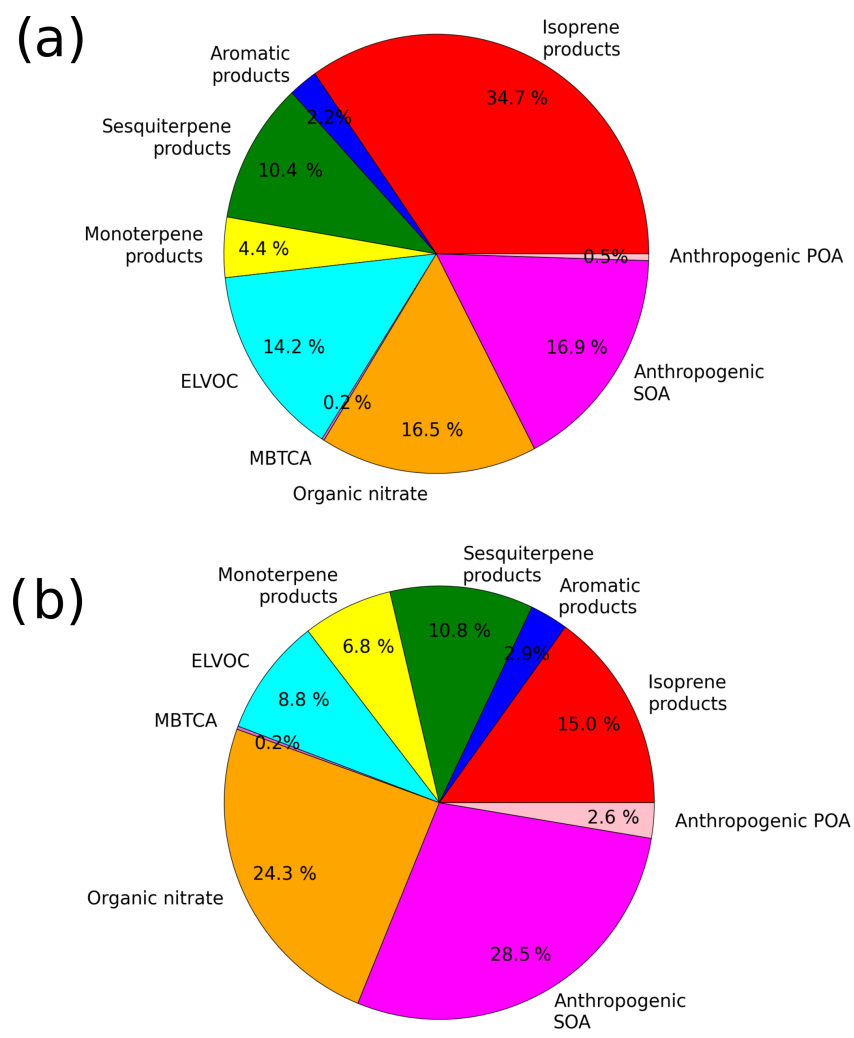

Figure 9. Modelled averaged composition of $\mathrm{OA}_{1}$ along the flight path during the (a) RF20 and (b) RF23 flights. This averaged composition is obtained by averaging concentrations along the flight path at altitudes below $1000 \mathrm{~m}$.

The measured organic matter is highly oxidized during both flights with an average measured $\mathrm{O}: \mathrm{C}$ ratio of 1.05 below $1000 \mathrm{~m}$ during the RF20 flight and 1.1 during the RF23 flight. This ratio is very well represented by the model with average values of 1.07 (RF20) and 1.17 (RF23). In the model, these high $\mathrm{O}: \mathrm{C}$ ratios arise because of organic compounds from isoprene oxidation, which all have an $\mathrm{O}: \mathrm{C}$ ratio greater than 0.8 , as well as some ELVOC compounds (monomers) from monoterpene oxidation. We can conclude from these observations that the low-volatility products (ELVOCs) from monoterpene oxidation as well as isoprene oxidation products may therefore correspond to the measured LOOA concentrations. Although the SOA contribution of anthropogenic VOC precursors is low (Couvidat et al., 2013; Sartelet et al., 2018), the results of the model show a high contribution of anthropogenic compounds (up to $30 \%$ ). These anthropogenic compounds could correspond to the regionally transported SOA, potentially identified as MOOA.

\section{Conclusion}

This paper characterizes aerosol and gas-phase physical and chemical properties over two different forested areas in southern France. During four dedicated flights, aerosol particles and gas-phase composition were measured using a cToF-AMS and a PTR-MS, respectively, with the principle objective of characterizing biogenic emissions. Aerosol particle physical properties were measured using a number of different techniques characterizing particle size and number concentrations. Using a combination of aerosol size distributions coupled with VOC concentrations we observe that although new particle formation seems to occur over all types of vegetation (mainly isoprene-emitting species or mainly monoterpene-emitting species), that low isopreneC / monoterpeneC ratio can favour the formation of fine aerosol particles. These VOC species likely condense on pre-existing particles that can then be chemically analysed.

During eastern flights, in valley areas, high concentrations of organic aerosol and biogenic VOC species were measured (isoprene and its oxidation products MACR + MVK + ISOPOOH). PMF analysis of the organic mass spectra separated two organic factors, namely a more-oxidized organic aerosol (MOOA) and a lessoxidized organic aerosol (LOOA). The MOOA species were strongly associated with $\mathrm{SO}_{4}$ species whereas the LOOA species were not related to inorganic species but correlated with temporal evolutions of biogenic oxidation products (MACR + MVK + ISOPOOH). Correlation with other precursor biogenic or aromatic VOC species was very weak.

A lack of direct evidence of IEPOX SOA $(\mathrm{m} / z 82$ $\mathrm{C}_{5} \mathrm{H}_{6} \mathrm{O}^{+}$) in the cToF-AMS measurements leads us to conclude that the formation of SOA, following an IEPOX formation route from isoprene precursor species was not dominant during this measurement period. The Polyphemus model determines a contribution of isoprene SOA, formed through alternative pathways, of the order of 15 to $35 \%$. Therefore, although not possible to accurately identify the formation pathway of the measured SOA, we can, based on its correlation with the oxidation products of isoprene, propose that it is at least partly associated with biogenic isoprene VOC species. The model also illustrates that although the emission of monoterpene and sesquiterpene species is low compared to that of isoprene, the yield of SOA formation from these precursor species is important. This is in agreement with recent observations by Zhang et al. (2018), who showed that SOA is principally formed from monoterpene emissions in the southern USA.

The model results estimate an overall contribution of $66 \%$ biogenic species and approximately $30 \%$ anthropogenic influence to the formation of SOA. The model can successfully replicate the measured OA during the flights, as well as the OA oxidation properties. However, the detailed molecular information obtained in the model (isoprene SOA, monoterpene SOA, organic nitrate) was not easily comparable to 
measurements. The model resolved organic nitrate contributions up to 17 to $23 \%$. This high contribution of organic nitrate is not reflected in the CToF-AMS measurements where nitrate contributed less than $5 \%$ to the measured $\mathrm{PM}_{1}$ mass. This difference is possibly due to nitrate hydrolysis that is not considered in the mode.

This study takes advantage of measurements sampling regional air masses that were gradually enriched with biogenic compounds, allowing us to evaluate the contribution of biogenic SOA in ambient environments. These measurements are compared directly with model simulations, highlighting that there are several atmospheric processes that cannot be neglected by atmospheric models (e.g contribution of ELVOC), as well as emphasizing important processes that need to be implemented into future model simulations (e.g. hydrolysis of organic nitrates).

Data availability. All data used in this work as well as all other data related to the ChArMEx program are available at http://mistrals. sedoo.fr/ChArMEx/, or can be requested directly from the corresponding author (e.freney@uca.fr).

\section{The Supplement related to this article is available online at https://doi.org/10.5194/acp-18-7041-2018-supplement.}

Competing interests. The authors declare that they have no conflict of interest.

Special issue statement. This article is part of the special issue "CHemistry and AeRosols Mediterranean EXperiments (ChArMEx) (ACP/AMT inter-journal SI)". It is not associated with a conference.

Acknowledgements. This study received financial support from MISTRALS by ADEME, CEA, INSU, and the project MeteoFrance. This research was also funded by the SAFMED (Secondary Aerosol Formation in the Mediterranean) ANR, (grant number ANR-12-BS06-0013-2502). The authors would like to extend a special thanks to the pilots and flight crew from SAFIRE for all their enthusiasm and support during the measurement campaign aboard the ATR42 aircraft. In addition, the authors are very grateful to Eric Hamonou for his logistical help in organizing the campaign, and to Laurence Fleury, Hélène Ferré, and the OMP/SEDOO team, who provided excellent support for aircraft operations through the ChOC web interface set-up and management.

Edited by: Xavier Querol

Reviewed by: Nicolas Marchand and two anonymous referees

\section{References}

Adachi, K., Zaizen, Y., Kajino, M., and Igarashi, Y.: Mixing state of regionally transported soot particles and the coating effect on their size and shape at a mountain site in Japan, J. Geophys. Res.-Atmos., 119, 5386-5396, https://doi.org/10.1002/2013JD020880, 2014.

Ait-Helal, W., Borbon, A., Sauvage, S., de Gouw, J. A., Colomb, A., Gros, V., Freutel, F., Crippa, M., Afif, C., Baltensperger, U., Beekmann, M., Doussin, J.-F., Durand-Jolibois, R., Fronval, I., Grand, N., Leonardis, T., Lopez, M., Michoud, V., Miet, K., Perrier, S., Prévôt, A. S. H., Schneider, J., Siour, G., Zapf, P., and Locoge, N.: Volatile and intermediate volatility organic compounds in suburban Paris: variability, origin and importance for SOA formation, Atmos. Chem. Phys., 14, 10439-10464, https://doi.org/10.5194/acp-14-10439-2014, 2014.

Alados-Arboledas, L., Müller, D., Guerrero-Rascado, J. L., NavasGuzmán, F., Pérez-Ramírez, D., and Olmo, F. J.: Optical and microphysical properties of fresh biomass burning aerosol retrieved by Raman lidar, and star-and sun-photometry, Geophys. Res. Lett., 38, L01807, https://doi.org/10.1029/2010GL045999, 2011.

Allan, J. D., Alfarra, M. R., Bower, K. N., Coe, H., Jayne, J. T., Worsnop, D. R., Aalto, P. P., Kulmala, M., Hyötyläinen, T., Cavalli, F., and Laaksonen, A.: Size and composition measurements of background aerosol and new particle growth in a Finnish forest during QUEST 2 using an Aerodyne Aerosol Mass Spectrometer, Atmos. Chem. Phys., 6, 315-327, https://doi.org/10.5194/acp-6315-2006, 2006.

Allan, J. D., Morgan, W. T., Darbyshire, E., Flynn, M. J., Williams, P. I., Oram, D. E., Artaxo, P., Brito, J., Lee, J. D., and Coe, H.: Airborne observations of IEPOX-derived isoprene SOA in the Amazon during SAMBBA, Atmos. Chem. Phys., 14, 11393 11407, https://doi.org/10.5194/acp-14-11393-2014, 2014.

Arneth, A., Monson, R. K., Schurgers, G., Niinemets, Ü., and Palmer, P. I.: Why are estimates of global terrestrial isoprene emissions so similar (and why is this not so for monoterpenes)?, Atmos. Chem. Phys., 8, 4605-4620, https://doi.org/10.5194/acp8-4605-2008, 2008.

Bahreini, R., Dunlea, E. J., Matthew, B. M., Simons, C., Docherty, K. S., DeCarlo, P. F., Jimenez, J. L., Brock, C. A., and Middlebrook, A. M.: Design and operation of a pressure-controlled inlet for airborne sampling with an aerodynamic aerosol lens, Aerosol Sci. Tech., 42, 465-471, https://doi.org/10.1080/02786820802178514, 2008.

Barnaba, F. and Gobbi, G. P.: Aerosol seasonal variability over the Mediterranean region and relative impact of maritime, continental and Saharan dust particles over the basin from MODIS data in the year 2001, Atmos. Chem. Phys., 4, 2367-2391, https://doi.org/10.5194/acp-4-2367-2004, 2004.

Baumgardner, D., Kok, G. L., and Raga, G. B.: On the diurnal variability of particle properties related to light absorbing carbon in Mexico City, Atmos. Chem. Phys., 7, 2517-2526, https://doi.org/10.5194/acp-7-2517-2007, 2007.

Bonn, B., Bourtsoukidis, E., Sun, T. S., Bingemer, H., Rondo, L., Javed, U., Li, J., Axinte, R., Li, X., Brauers, T., Sonderfeld, H., Koppmann, R., Sogachev, A., Jacobi, S., and Spracklen, D. V.: The link between atmospheric radicals and newly formed particles at a spruce forest site in Germany, Atmos. Chem. 
Phys., 14, 10823-10843, https://doi.org/10.5194/acp-14-108232014, 2014.

Borbon, A., Gilman, J. B., Kuster, W. C., Grand, N., Chevaillier, S., Colomb, A., Dolgorouky, C., Gros, V., Lopez, M., Sarda-Esteve, R., Holloway, J., Stutz, J., Perrussel, O., Petetin, H., McKeen, S., Beekmann, M., Warneke, C., Parrishand, D. D., and de Gouw, J. A.: Emission ratios of anthropogenic VOC in northern mid latitude megacities: observations vs. emission inventories in Los Angeles and Paris, J. Geophys. Res., 118, 2041-2057, 2013.

Bryan, A. M., Bertman, S. B., Carroll, M. A., Dusanter, S., Edwards, G. D., Forkel, R., Griffith, S., Guenther, A. B., Hansen, R. F., Helmig, D., Jobson, B. T., Keutsch, F. N., Lefer, B. L., Pressley, S. N., Shepson, P. B., Stevens, P. S., and Steiner, A. L.: In-canopy gas-phase chemistry during CABINEX 2009: sensitivity of a 1D canopy model to vertical mixing and isoprene chemistry, Atmos. Chem. Phys., 12, 8829-8849, https://doi.org/10.5194/acp12-8829-2012, 2012.

Budisulistiorini, S. H., Li, X., Bairai, S. T., Renfro, J., Liu, Y., Liu, Y. J., McKinney, K. A., Martin, S. T., McNeill, V. F., Pye, H. O. T., Nenes, A., Neff, M. E., Stone, E. A., Mueller, S., Knote, C., Shaw, S. L., Zhang, Z., Gold, A., and Surratt, J. D.: Examining the effects of anthropogenic emissions on isoprenederived secondary organic aerosol formation during the 2013 Southern Oxidant and Aerosol Study (SOAS) at the Look Rock, Tennessee ground site, Atmos. Chem. Phys., 15, 8871-8888, https://doi.org/10.5194/acp-15-8871-2015, 2015.

Capes, G., Murphy, J. G., Reeves, C. E., McQuaid, J. B., Hamilton, J. F., Hopkins, J. R., Crosier, J., Williams, P. I., and Coe, H.: Secondary organic aerosol from biogenic VOCs over West Africa during AMMA, Atmos. Chem. Phys., 9, 3841-3850, https://doi.org/10.5194/acp-9-3841-2009, 2009.

Chrit, M., Sartelet, K., Sciare, J., Pey, J., Marchand, N., Couvidat, F., Sellegri, K., and Beekmann, M.: Modelling organic aerosol concentrations and properties during ChArMEx summer campaigns of 2012 and 2013 in the western Mediterranean region, Atmos. Chem. Phys., 17, 12509-12531, https://doi.org/10.5194/acp-17-12509-2017, 2017.

Chrit, M., Sartelet, K., Sciare, J., Pey, J., Nicolas, J. B., Marchand, N., Freney, E., Sellegri, K., Beekmann, M., and Dulac, F.: Aerosol sources in the western Mediterranean during summertime: A model-based approach, Atmos. Chem. Phys. Discuss., https://doi.org/10.5194/acp-2017-915, in review, 2018.

Couvidat, F. and Sartelet, K.: The Secondary Organic Aerosol Processor (SOAP v1.0) model: a unified model with different ranges of complexity based on the molecular surrogate approach, Geosci. Model Dev., 8, 1111-1138, https://doi.org/10.5194/gmd8-1111-2015, 2015.

Couvidat, F., Debry, E., Sartelet, K. N., and Seigneur, C.: A hydrophilic/hydrophobic organic $\left(\mathrm{H}^{2} \mathrm{O}\right)$ aerosol model: Development, evaluation and sensitivity analysis, J. Geophys. Res., 117, D10304, https://doi.org/10.1029/2011JD017214, 2012.

Couvidat, F., Kim, Y., Sartelet, K., Seigneur, C., Marchand, N., and Sciare, J.: Modeling secondary organic aerosol in an urban area: application to Paris, France, Atmos. Chem. Phys., 13, 983-996, https://doi.org/10.5194/acp-13-983-2013, 2013.

Crumeyrolle, S., Schwarzenboeck, A., Roger, J. C., Sellegri, K., Burkhart, J. F., Stohl, A., Gomes, L., Quennehen, B., Roberts, G., Weigel, R., Villani, P., Pichon, J. M., Bourrianne, T., and Laj, P.: Overview of aerosol properties associated with air masses sam- pled by the ATR-42 during the EUCAARI campaign (2008), Atmos. Chem. Phys., 13, 4877-4893, https://doi.org/10.5194/acp13-4877-2013, 2013.

Day, D. A., Takahama, S., Gilardoni, S., and Russell, L. M.: Organic composition of single and submicron particles in different regions of western North America and the eastern Pacific during INTEX-B 2006, Atmos. Chem. Phys., 9, 5433-5446, https://doi.org/10.5194/acp-9-5433-2009, 2009.

Debry, E., Fahey, K., Sartelet, K., Sportisse, B., and Tombette, M.: Technical Note: A new SIze REsolved Aerosol Model (SIREAM), Atmos. Chem. Phys., 7, 1537-1547, https://doi.org/10.5194/acp-7-1537-2007, 2007.

Drewnick, F., Hings, S. S., DeCarlo, P. F., Jayne, J. T., Gonin, M., Fuhrer, K., Weimer, S., Jimenez, J. L., Demerjian, K. L., Borrmann, S., Worsnop, D. R.: A new Time-of-Flight Aerosol Mass Spectrometer (ToF-AMS): Instrument Description and First Field Deployment, Aerosol Sci. Tech., 39, 637-658, 2005.

Ganzeveld, L., Eerdekens, G., Feig, G., Fischer, H., Harder, H., Königstedt, R., Kubistin, D., Martinez, M., Meixner, F. X., Scheeren, H. A., Sinha, V., Taraborrelli, D., Williams, J., VilàGuerau de Arellano, J., and Lelieveld, J.: Surface and boundary layer exchanges of volatile organic compounds, nitrogen oxides and ozone during the GABRIEL campaign, Atmos. Chem. Phys., 8, 6223-6243, https://doi.org/10.5194/acp-8-6223-2008, 2008.

Gaston, C. J., Riedel, T. P., Zhang, Z., Gold, A., Surratt, J. D., and Thornton, J. A.: Reactive uptake of an isoprene-derived epoxydiol to submicron aerosol particles, Environ. Sci. Technol., 48, 11178-11186, https://doi.org/10.1021/es5034266, 2014.

Guenther, A., Karl, T., Harley, P., Wiedinmyer, C., Palmer, P. I., and Geron, C.: Estimates of global terrestrial isoprene emissions using MEGAN (Model of Emissions of Gases and Aerosols from Nature), Atmos. Chem. Phys., 6, 3181-3210, https://doi.org/10.5194/acp-6-3181-2006, 2006.

Hallquist, M., Wenger, J. C., Baltensperger, U., Rudich, Y., Simpson, D., Claeys, M., Dommen, J., Donahue, N. M., George, C., Goldstein, A. H., Hamilton, J. F., Herrmann, H., Hoffmann, T., Iinuma, Y., Jang, M., Jenkin, M. E., Jimenez, J. L., Kiendler-Scharr, A., Maenhaut, W., McFiggans, G., Mentel, Th. F., Monod, A., Prévôt, A. S. H., Seinfeld, J. H., Surratt, J. D., Szmigielski, R., and Wildt, J.: The formation, properties and impact of secondary organic aerosol: current and emerging issues, Atmos. Chem. Phys., 9, 5155-5236, https://doi.org/10.5194/acp9-5155-2009, 2009.

Held, A., Nowak, A., Birmili, W., Wiedensohler, A., Forkel, R., and Klemm, O.: Observations of particle formation and growth in a mountainous forest region in central Europe, J. Geophys. Res.Atmos., 109, D23204, https://doi.org/10.1029/2004JD005346, 2004.

Hu, W. W., Campuzano-Jost, P., Palm, B. B., Day, D. A., Ortega, A. M., Hayes, P. L., Krechmer, J. E., Chen, Q., Kuwata, M., Liu, Y. J., de Sá, S. S., McKinney, K., Martin, S. T., Hu, M., Budisulistiorini, S. H., Riva, M., Surratt, J. D., St. Clair, J. M., Isaacman-Van Wertz, G., Yee, L. D., Goldstein, A. H., Carbone, S., Brito, J., Artaxo, P., de Gouw, J. A., Koss, A., Wisthaler, A., Mikoviny, T., Karl, T., Kaser, L., Jud, W., Hansel, A., Docherty, K. S., Alexander, M. L., Robinson, N. H., Coe, H., Allan, J. D., Canagaratna, M. R., Paulot, F., and Jimenez, J. L.: Characterization of a real-time tracer for isoprene epoxydiols-derived secondary organic aerosol (IEPOX-SOA) from aerosol mass spec- 
trometer measurements, Atmos. Chem. Phys., 15, 11807-11833, https://doi.org/10.5194/acp-15-11807-2015, 2015.

IPCC: Climate Change 2007: The Physical Science Basis, Intergovernmental Panel for Climate Change Working Group I Rep., edited by: Solomon, S., Qin, D., Manning, M., Chen, Z., Marquis, M., Averyt, K. B., Tignor, M., and Miller, H. L., Cambridge University Press, 2007.

Jacobs, M. I., Burke, W. J., and Elrod, M. J.: Kinetics of the reactions of isoprene-derived hydroxynitrates: gas phase epoxide formation and solution phase hydrolysis, Atmos. Chem. Phys., 14, 8933-8946, https://doi.org/10.5194/acp-14-8933-2014, 2014.

Kanawade, V. P., Jobson, B. T., Guenther, A. B., Erupe, M. E., Pressley, S. N., Tripathi, S. N., and Lee, S.-H.: Isoprene suppression of new particle formation in a mixed deciduous forest, Atmos. Chem. Phys., 11, 6013-6027, https://doi.org/10.5194/acp11-6013-2011, 2011.

Kesselmeier, J. and Staudt, M.: Biogenic volatile organic compounds (VOC): An overview on emission, physiology and ecology, J. Atmos. Chem., 33, 23-88, https://doi.org/10.1023/A:1006127516791, 1999.

Kiendler-Scharr, A., Wildt, J., Dal Maso, M., Hohaus, T., Kleist, E., Mentel, T. F., Tillmann, R., Uerlings, R., Schurr, U., and Wahner, A.: New particle formation in forests inhibited by isoprene emissions, Nature, 461, 381-384, https://doi.org/10.1038/nature08292, 2009.

Kulmala, M., Hämeri, K., Mäkelä, J. M., Aalto, P. P., Pirjola, L., Väkevä, M., Nilsson, E. D., Koponen, I. K., Buzorius, G., Keronen, P., Rannik, Ü, Laakso, L., Vesala, T., Bigg, K., Seidl, W., Forkel, R., Hoffmann, T., Spanke, J., Janson, R., Shimmo, M., Hansson, H.-C., O’Dowd, C., Becker, E., Paatero, J., Teinilä, K., Hillamo, R., Viisanen, Y., Laaksonen, A., Swietlicki, E., Salm, J., Hari, P., Altimir, N., and Weber, R.: Biogenic aerosol formation in the boreal forest, Boreal Environ. Res., 5, 281-297, 2000.

Laakso, L., Merikanto, J., Vakkari, V., Laakso, H., Kulmala, M., Molefe, M., Kgabi, N., Mabaso, D., Carslaw, K. S., Spracklen, D. V., Lee, L. A., Reddington, C. L., and Kerminen, V.M.: Boundary layer nucleation as a source of new $\mathrm{CCN}$ in savannah environment, Atmos. Chem. Phys., 13, 1957-1972, https://doi.org/10.5194/acp-13-1957-2013, 2013.

Lee, A. K. Y., Abbatt, J. P. D., Leaitch, W. R., Li, S.-M., Sjostedt, S. J., Wentzell, J. J. B., Liggio, J., and Macdonald, A. M.: Substantial secondary organic aerosol formation in a coniferous forest: observations of both day- and nighttime chemistry, Atmos. Chem. Phys., 16, 6721-6733, https://doi.org/10.5194/acp16-6721-2016, 2016.

Lelieveld, J., Butler, T. M., Crowley, J. N., Dillon, T. J., Fischer, H., Ganzeveld, L., Harder, H., Lawrence, M. G., Martinez, M., Taraborrelli, D., and Williams, J.: Atmospheric oxidation capacity sustained by a tropical forest, Nature, 452, 737-740, https://doi.org/10.1038/nature06870, 2008.

Loreto, F., Ciccioli, P., Cecinato, A., Brancaleoni, E., Frattoni, M., Fabozzi, C., and Tricoli, D.: Evidence of the photosynthetic origin of monoterpene emitted by Quercus ilex L. leaves by ${ }^{13} \mathrm{C}$ labelling, Plant Physiol., 110, 1317-1322, https://doi.org/10.1104/pp.110.4.1317, 1996.

Lyamani, H., Olmo, F. J., Alcántara, A., and Alados-Arboledas, L.: Atmospheric aerosols during the 2003 heat wave in southeastern Spain I: Spectral optical depth, Atmos. Environ., 40, 6453-6464, https://doi.org/10.1016/j.atmosenv.2006.04.048, 2006.
Mallet, M., Dubovik, O., Nabat, P., Dulac, F., Kahn, R., Sciare, J., Paronis, D., and Léon, J. F.: Absorption properties of Mediterranean aerosols obtained from multi-year ground-based remote sensing observations, Atmos. Chem. Phys., 13, 9195-9210, https://doi.org/10.5194/acp-13-9195-2013, 2013.

Markowitz, K. M., Flatau, P. J., Ramana, M. V., Crutzen, P. J., and Ramanathan, V.: Absorbing Mediterranean aerosols lead to a large reduction in the solar radiation at the surface, Geophys. Res. Lett., 29, 1968, https://doi.org/10.1029/2002GL015767, 2002.

Martin, S. T., Andreae, M. O., Artaxo, P., Baumgardner, D., Chen, Q., Goldstein, A. H., Guenther, A., Heald, C. L., Mayol-Bracero, O. L., McMurry, P. H., Pauliquevis, T., Pöschl, U., Prather, K. A., Roberts, G. C., Saleska, S. R., Silva Dias, M. A., Spracklen, D. V., Swietlicki, E., and Trebs, I.: Sources and properties of Amazonian aerosol particles, Rev. Geophys., 48, RG2002, https://doi.org/10.1029/2008RG000280, 2010.

Middlebrook, A. N., Bahreini, R., Jimenez, J. L., and Canagaratna, M. R.: Evaluation of composition-dependent collection efficiencies for the Aerodyne aerosol mass spectrometer using field data, Aerosol Sci. Tech., 46, 258-271, https://doi.org/10.1080/02786826.2011.620041, 2012.

Nedelec, P., Cammas, J.-P., Thouret, V., Athier, G., Cousin, J.-M., Legrand, C., Abonnel, C., Lecoeur, F., Cayez, G., and Marizy, C.: An improved infrared carbon monoxide analyser for routine measurements aboard commercial Airbus aircraft: technical validation and first scientific results of the MOZAIC III programme, Atmos. Chem. Phys., 3, 1551-1564, https://doi.org/10.5194/acp3-1551-2003, 2003.

Nenes, A., Pandis, S. N., and Pilinis, C.: ISORROPIA: A new thermodynamic equilibrium model for multiphase multicomponent inorganic aerosols, Aquat. Geochem., 4, 123-152, https://doi.org/10.1023/A:1009604003981, 1998.

Nguyen, T. B., Coggon, M. M., Bates, K. H., Zhang, X., Schwantes, R. H., Schilling, K. A., Loza, C. L., Flagan, R. C., Wennberg, P. O., and Seinfeld, J. H.: Organic aerosol formation from the reactive uptake of isoprene epoxydiols (IEPOX) onto nonacidified inorganic seeds, Atmos. Chem. Phys., 14, 3497-3510, https://doi.org/10.5194/acp-14-3497-2014, 2014.

Odum, J. R., Hoffmann, T., Bowman, F., Collins, D. C., Flagan, R. H., and Seinfeld, J.: Gas/Particle Partitioning and Secondary Organic Aerosol Yields, Environ. Sci. Tech., 30, https://doi.org/10.1021/es950943, 1996.

Paatero, P. and Tapper, U.: Positive matrix factorization: A non-negative factor model with optimal utilization of error estimates of data values, Environmetrics, 5, 111-126, https://doi.org/10.1002/env.3170050203, 1994.

Palm, B. B., de Sá, S. S., Day, D. A., Campuzano-Jost, P., Hu, W., Seco, R., Sjostedt, S. J., Park, J.-H., Guenther, A. B., Kim, S., Brito, J., Wurm, F., Artaxo, P., Thalman, R., Wang, J., Yee, L. D., Wernis, R., Isaacman-VanWertz, G., Goldstein, A. H., Liu, Y., Springston, S. R., Souza, R., Newburn, M. K., Alexander, M. L., Martin, S. T., and Jimenez, J. L.: Secondary organic aerosol formation from ambient air in an oxidation flow reactor in central Amazonia, Atmos. Chem. Phys., 18, 467-493, https://doi.org/10.5194/acp-18-467-2018, 2018.

Papadimas, C. D., Hatzianastassiou, N., Matsoukas, C., Kanakidou, M., Mihalopoulos, N., and Vardavas, I.: The direct effect of aerosols on solar radiation over the broader 
Mediterranean basin, Atmos. Chem. Phys., 12, 7165-7185, https://doi.org/10.5194/acp-12-7165-2012, 2012.

Rindelaub, J. D., Borca, C. H., Hostetler, M. A., Slade, J. H., Lipton, M. A., Slipchenko, L. V., and Shepson, P. B.: The acid-catalyzed hydrolysis of an $\alpha$-pinene-derived organic nitrate: kinetics, products, reaction mechanisms, and atmospheric impact, Atmos. Chem. Phys., 16, 15425-15432, https://doi.org/10.5194/acp-1615425-2016, 2016.

Riva, M., Budisulistiorini, S. H., Zhang, Z., Gold, A., and Surratt, J. D.: Chemical characterization of secondary organic aerosol constituents from isoprene ozonolysis in the presence of acidic aerosol, Atmos. Environ., 130, 5-13, 2016.

Robinson, N. H., Hamilton, J. F., Allan, J. D., Langford, B., Oram, D. E., Chen, Q., Docherty, K., Farmer, D. K., Jimenez, J. L., Ward, M. W., Hewitt, C. N., Barley, M. H., Jenkin, M. E., Rickard, A. R., Martin, S. T., McFiggans, G., and Coe, H.: Evidence for a significant proportion of Secondary Organic Aerosol from isoprene above a maritime tropical forest, Atmos. Chem. Phys., 11, 1039-1050, https://doi.org/10.5194/acp11-1039-2011, 2011.

Sartelet, K. N., Couvidat, F., Seigneur, C., and Roustan, Y.: Impact of biogenic emissions on air quality over Europe and North America, Atmos. Environ., 53, 131-141, https://doi.org/10.1016/j.atmosenv.2011.10.046, 2012.

Sartelet, K., Zhu, S., Moukhtar, S., André, M., André, J. M., Gros, V., Favez, O., Brasseur, A., and Redaelli, M.: Emission of intermediate, semi and low volatile organic compounds from traffic and their impact on secondary organic aerosol concentrations over Greater Paris, Atmos. Environ., 180, 126-137, https://doi.org/10.1016/j.atmosenv.2018.02.031, 2018.

Schwartz, R. E., Russell, L. M., Sjostedt, S. J., Vlasenko, A., Slowik, J. G., Abbatt, J. P. D., Macdonald, A. M., Li, S. M., Liggio, J., Toom-Sauntry, D., and Leaitch, W. R.: Biogenic oxidized organic functional groups in aerosol particles from a mountain forest site and their similarities to laboratory chamber products, Atmos. Chem. Phys., 10, 5075-5088, https://doi.org/10.5194/acp-10-5075-2010, 2010.

Sciare, J., Bardouki, H., Moulin, C., and Mihalopoulos, N.: Aerosol sources and their contribution to the chemical composition of aerosols in the Eastern Mediterranean Sea during summertime, Atmos. Chem. Phys., 3, 291-302, https://doi.org/10.5194/acp-3291-2003, 2003.

Setyan, A., Song, C., Merkel, M., Knighton, W. B., Onasch, T. B., Canagaratna, M. R., Worsnop, D. R., Wiedensohler, A., Shilling, J. E., and Zhang, Q.: Chemistry of new particle growth in mixed urban and biogenic emissions - insights from CARES, Atmos. Chem. Phys., 14, 6477-6494, https://doi.org/10.5194/acp14-6477-2014, 2014.

Shilling, J. E., Zaveri, R. A., Fast, J. D., Kleinman, L., Alexander, M. L., Canagaratna, M. R., Fortner, E., Hubbe, J. M., Jayne, J. T., Sedlacek, A., Setyan, A., Springston, S., Worsnop, D. R., and Zhang, Q.: Enhanced SOA formation from mixed anthropogenic and biogenic emissions during the CARES campaign, Atmos. Chem. Phys., 13, 2091-2113, https://doi.org/10.5194/acp-132091-2013, 2013.

Sihto, S.-L., Kulmala, M., Kerminen, V.-M., Dal Maso, M., Petäjä, T., Riipinen, I., Korhonen, H., Arnold, F., Janson, R., Boy, M., Laaksonen, A., and Lehtinen, K. E. J.: Atmospheric sulphuric acid and aerosol formation: implications from atmospheric mea- surements for nucleation and early growth mechanisms, Atmos. Chem. Phys., 6, 4079-4091, https://doi.org/10.5194/acp-6-40792006, 2006.

Slowik, J. G., Stroud, C., Bottenheim, J. W., Brickell, P. C., Chang, R. Y.-W., Liggio, J., Makar, P. A., Martin, R. V., Moran, M. D., Shantz, N. C., Sjostedt, S. J., van Donkelaar, A., Vlasenko, A., Wiebe, H. A., Xia, A. G., Zhang, J., Leaitch, W. R., and Abbatt, J. P. D.: Characterization of a large biogenic secondary organic aerosol event from eastern Canadian forests, Atmos. Chem. Phys., 10, 2825-2845, https://doi.org/10.5194/acp-102825-2010, 2010.

Spracklen, D. V., Bonn, B., and Carslaw, K. S.: Boreal forests, aerosols and the impacts on clouds and climate, Philos. T. Roy. Soc. Lond. A Mat., 366, 4613-4626, https://doi.org/10.1098/rsta.2008.0201, 2008.

Ulbrich, I. M., Canagaratna, M. R., Zhang, Q., Worsnop, D. R., and Jimenez, J. L.: Interpretation of organic components from Positive Matrix Factorization of aerosol mass spectrometric data, Atmos. Chem. Phys., 9, 2891-2918, https://doi.org/10.5194/acp-92891-2009, 2009.

Yarwood, G., Rao, S., Yocke, M., and Whitten, G.: Updates to the carbon bond chemical mechanism: CB05. Rep. RT-0400675, 246 pp., available at: http://www.camx.com/files/cb05_final_ report_120805.aspx (last access: 27 March 2017), 2005.

Zannoni, N., Gros, V., Lanza, M., Sarda, R., Bonsang, B., Kalogridis, C., Preunkert, S., Legrand, M., Jambert, C., Boissard, C., and Lathiere, J.: OH reactivity and concentrations of biogenic volatile organic compounds in a Mediterranean forest of downy oak trees, Atmos. Chem. Phys., 16, 1619-1636, https://doi.org/10.5194/acp-16-1619-2016, 2016.

Zhang, H., Yee, L. D., Lee, B. H., Curtis, M. P., Worton, D. R., Isaacman-VanWertz, G., Offenberg, J. H., Lewandowski, M., Kleindienst, T. E., Beaver, M. E., Holder, A. L., Lonneman, W. A., Docherty, K. S., Jaoui, M., Pye, H. O. T., Hu, W., Day, D. D., Campuzano-Jost, P., Jimenez, J., Guo, H., Weber, R. J., de Gouw, J., Koss, A. R, Edgerton, E. S., Brune, W., Mohr, C., Lopez-Hilfiker, F. D., Lutz, A., Kreisberg, N. M., Spielman, S. R., Hering, S., Wilson, K. R., Thornton, J. A, and Goldstein, A. H.: Monoterpene SOA dominate atmospheric fine aerosol, P. Natl. Acad. Sci. USA, 115, 2038-2043, https://doi.org/10.1073/pnas.1717513115, 2018.

Zhang, Y., Tang, L., Sun, Y., Favez, O., Canonaco, F., Albinet, A., Couvidat, F., Liu, D., Jayne, J. T., Wang, Z., Croteau, P. L., Canagaratna, M. R., Zhou, H.-C., Prévôt, A. S. H., and Worsnop, D. R.: Limited formation of isoprene epoxydiolsderived secondary organic aerosol under $\mathrm{NO}_{x}$-rich environments in Eastern China, Geophys. Res. Lett., 44, 2035-2043, https://doi.org/10.1002/2016GL072368, 2017.

Zhu, S., Sartelet, K., Healy, R., and Wenger, J.: Simulation of particle diversity and mixing state over Greater Paris: A modelmeasurement inter-comparison, Faraday Discuss., 189, 547566, https://doi.org/10.1039/C5FD00175G, 2016. 